Portland State University

PDXScholar

Summer 9-5-2013

\title{
Characterization of Secondary Organic Aerosol Precursors Using Two-Dimensional Gas Chromatography with Time of Flight Mass Spectrometry (GC×GC/TOFMS)
}

Melissa Jordan Roskamp

Portland State University

Follow this and additional works at: https://pdxscholar.library.pdx.edu/open_access_etds

Part of the Atmospheric Sciences Commons, and the Environmental Engineering Commons Let us know how access to this document benefits you.

\section{Recommended Citation}

Roskamp, Melissa Jordan, "Characterization of Secondary Organic Aerosol Precursors Using TwoDimensional Gas Chromatography with Time of Flight Mass Spectrometry (GC×GC/TOFMS)" (2013). Dissertations and Theses. Paper 1411.

https://doi.org/10.15760/etd.1411

This Thesis is brought to you for free and open access. It has been accepted for inclusion in Dissertations and Theses by an authorized administrator of PDXScholar. Please contact us if we can make this document more accessible: pdxscholar@pdx.edu. 
Characterization of Secondary Organic Aerosol Precursors Using Two-Dimensional Gas Chromatography with Time of Flight Mass Spectrometry (GC×GC/TOFMS)

by

Melissa Jordan Roskamp

A thesis submitted in partial fulfillment of the requirements for the degree of

Master of Science

in

Civil and Environmental Engineering

Thesis Committee:

Kelley Barsanti, Chair

James Pankow

Todd Rosenstiel

Portland State University

2013 


\begin{abstract}
The oxidation of volatile organic compounds (VOCs) plays a role in both regional and global air quality through the formation of secondary organic aerosols (SOA). More than $1000 \mathrm{TgC} / \mathrm{yr}$ of non-methane VOCs are emitted from biogenic sources (significantly greater than from anthropogenic sources). Despite this magnitude and potential importance for air quality, the body of knowledge around the identities, quantities and oxidation processes of these compounds is still incomplete (e.g., Goldstein \& Galbally, 2007; Robinson et al., 2009). Two-dimensional gas chromatography paired with time-offlight mass spectrometry (GC $\times \mathrm{GC} / \mathrm{TOFMS})$ is a powerful analytical technique which is explored here for its role in better characterizing biogenic VOCs (BVOCs) and thus SOA precursors.
\end{abstract}

This work presents measurements of BVOCs collected during two field campaigns and analyzed using GC×GC/TOFMS. The first campaign, the Bio-hydro-atmosphere Interactions of Energy, Aerosols, Carbon, $\mathrm{H}_{2} \mathrm{O}$, Organics \& Nitrogen - Rocky Mountain Biogenic Aerosol Study (BEACHON-RoMBAS), took place in a Ponderosa pine forest in Colorado. The second campaign, Particle Investigations at a Northern Ozarks Tower: $\mathrm{NO}_{\mathrm{x}}$, Oxidant, Isoprene Research (PINOT NOIR) Study, was conducted in the Ozark region of Missouri. Tens to hundreds of BVOCs were quantified in each set of samples, including primary emissions, atmospheric oxidation products, stress indicators and semivolatile leaf surface compounds. These findings highlight that there is a largely uncharacterized diversity of BVOCs in ambient samples. Our findings demonstrate that GC $\times$ GC can distinguish between compounds with the same molecular weight and similar 
structures, which have highly variable potentials for production of SOA (Lee et al., 2006). This work represents some of the first analysis of ambient BVOCs with this technology, which is anticipated to contribute greatly to characterization of atmospheric SOA precursors and ultimately, regional and global modeling of SOA and fine particulate matter. 


\section{Acknowledgments}

I would like to express my deepest appreciation to my advisor and committee chair, Dr. Kelley Barsanti, for her guidance and support of my work at Portland State University.

I would also like to thank my committee members, Dr. James Pankow and Dr. Todd Rosensteil, for your insight and work reviewing this document.

To Dr. Wentai Luo, Lorne Isabelle and Dr. Lindsay Hatch—-thank you for your invaluable help with laboratory and analytical techniques. I would have been lost without your help.

Thank you to Andrew Turnipseed and Peter Harley of the National Center for Atmospheric Research, for collection of BEACHON-RoMBAS samples and for their assistance during the PINOT NOIR campaign.

It is an honor to have worked with so many outstanding researchers, without whom this thesis would not have been possible. 
Table of Contents

Abstract $\quad$ i

$\begin{array}{ll}\text { Acknowledgements } & \text { iii }\end{array}$

List of Tables $\quad$ V

List of Figures vi vi vi vis

I. Introduction $\quad 1$

II. Site Descriptions $\quad 8$

$\begin{array}{ll}\text { III. Methods } & 12\end{array}$

$\begin{array}{ll}\text { IV. Results and Discussions } & 22\end{array}$

$\begin{array}{ll}\text { V. Conclusions } & 38\end{array}$

$\begin{array}{ll}\text { References } & 41\end{array}$

Appendix A: Samples Collected During BEACHON-RoMBAS 47

Appendix B: Samples Collected During PINOT NOIR 48

Appendix C: Ozone Filters $\quad 51$

Appendix D: Authentic Standards Used in Analysis 52

Appendix E: Data Analysis Steps $\quad 53$

Appendix F: Compound List-BEACHON-RoMBAS 58

Appendix G: Compound List_PINOT NOIR 60 


\section{List of Tables}

Table 1: Summary of GC $\times$ GC/TOFMS conditions used for analysis of BEACHONRoMBAS and PINOT NOIR samples.

Table 2: Breakthrough experiments conducted during PINOT NOIR in which samples were collected onto two cartridges in series. 


\section{List of Figures}

Figure 1: Schematic of GC×GC Components 6

Figure 2: Google Earth Image of BEACHON-RoMBAS Site 8

Figure 3: Google Earth Image of PINOT-NOIR Site 10

Figure 4: Schematic of Sampling in BEACHON-RoMBAS Canopy 13

Figure 5: Schematic of Sampling in PINOT NOIR Canopy 13

Figure 6: Schematic of Sample Collection during PINOT-NOIR 15

Figure 7: GC×GC Temperature Programs 18

Figure 8: Column Chart of Monoterpene Makeup in BEACHON-RoMBAS 22

Figure 9: Day and Nighttime Monoterpene Makeup during BEACHON 23

Figure 10: GC×GC 3-D Chromatogram 24

Figure 11: Diurnal Concentrations of Terpenes during BEACHON 27

Figure 12: Schematic of Series Sample Collection during PINOT-NOIR 29

Figure 13: Results of Breakthrough Experiments 30

Figure 14: Comparison of MVK+Methyl Vinyl Ketone Measurements from the PTR-TOF-MS and GC $\times$ GC

Figure 15: Comparison of Isoprene Measurements from the PTR-TOF-MS and $\mathrm{GC} \times \mathrm{GC}$

Figure 16: Day and Nighttime Monoterpene Makeup during PINOT-NOIR

Figure 17: Comparison of Monoterpene Measurements from the PTR-TOF-MS and $\mathrm{GC} \times \mathrm{GC}$ 


\section{Introduction}

It is estimated that more than $1200 \mathrm{TgC}$ per year of volatile organic compounds (VOCs) are emitted into the troposphere from thousands of sources, both manmade and natural (Kim et al., 2010 and references therein). Manmade (anthropogenic) sources include combustion, manufacturing, and agriculture. Natural (biogenic) sources include plants, animals, and microbial decay of organic compounds. Current estimates show that

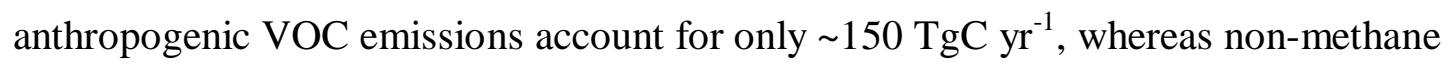

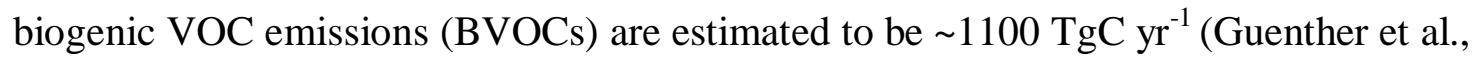
1995). In particular, more than 1700 BVOCs are known to be emitted by plants, the most important of which are the terpenoids-hemiterpenes (isoprene and 2-methyl-3-butene-2ol), monoterpenes $\left(\mathrm{C}_{10} \mathrm{H}_{16}\right)$, sesquiterpenes $\left(\mathrm{C}_{15} \mathrm{H}_{24}\right)$, and oxygenated terpenes (e.g., linalool, $\left.\mathrm{C}_{10} \mathrm{H}_{18} \mathrm{O}\right)$. Terpenes are produced by plants for a variety of physiological purposes, such as defense (Peñuelas and Llusiá, 2001) and for signaling plants/pollinators (Farmer and Ryan, 1990).

The oxidation of VOCs plays a major role in both regional and global air quality, primarily through production of ozone $\left(\mathrm{O}_{3}\right)$ and secondary organic aerosols (SOA). SOA is defined as liquid or solid particles generated through the atmospheric oxidation of reactive organics (Pankow, 1994; Kroll and Seinfeld, 2008). $\mathrm{O}_{3}$ and fine particulate matter $(<2.5 \mu \mathrm{m}$ in diameter — of which a large fraction may be SOA $)$ are criteria pollutants regulated by the US Environmental Protection Agency (US EPA) under the Clean Air Act. Criteria pollutants are defined as emissions that "cause or contribute to air pollution which may reasonably be anticipated to endanger public health or welfare." 
Tropospheric $\mathrm{O}_{3}$ is a powerful oxidant that acts as a pulmonary irritant and reduces lung function (Ebi and McGregor, 2008). Exposure to $\mathrm{PM}_{2.5}$ can cause significant health impacts, including cardiovascular and respiratory issues and even increased mortality (Pope and Dockery, 2006). Furthermore, $\mathrm{O}_{3}$ (a potent greenhouse gas) and $\mathrm{PM}_{2.5}$ affect the radiative balance of the earth and thus play key roles in global climate change (IPCC, 2007). Unfortunately, efforts to accurately predict future air quality and climate conditions are impeded by the incomplete identification and quantification of the most relevant atmospheric VOCs and their reaction products.

Because $\mathrm{O}_{3}$ and SOA are secondary pollutants, i.e. formed in the atmosphere via chemical and photochemical reactions, they have proved much more difficult than many primary pollutants to control and understand. Of the standards set for the six criteria pollutants regulated by the EPA, $\mathrm{O}_{3}$ and $\mathrm{PM}_{2.5}$ are the most often violated. Exposure to $\mathrm{O}_{3}$ and $\mathrm{PM}_{2.5}$ are thus estimated to pose the most widespread threats to human health (EPA, 2003). A challenge to $\mathrm{PM}_{2.5}$ management strategies is the fact that SOA yields have been shown to be highly variable depending on the identity of the individual precursor compounds (Lee et al. 2006; Fry et al. in prep.). Furthermore, controlled laboratory experiments have shown that experimental conditions such as $\mathrm{NO}_{\mathrm{x}}$ level $(\mathrm{Ng}$ et al, 2007), relative humidity (Zhang et al, 2011) and temperature (Sheehan and Bowman, 2001) also impact SOA formation. Understanding the atmospheric relevance of these differences will require the ability to measure and identify individual B VOCs.

Despite extensive research into the chemistry of BVOCs, field and laboratory studies indicate that the collection of knowledge around the identities, quantities and atmospheric 
oxidation processes of these ambient compounds is still incomplete (Robinson et al., 2009; Kim et al., 2010). For non-methane biogenic emissions, a review of the global budget indicates that sources, and thus SOA precursors, may be an order of magnitude larger than current estimates (Goldstein and Galbally, 2007). Of particular interest is whether unidentified or unmeasured BVOCs significantly contribute to this "missing mass" from the global budget.

In the 1950s the advent of gas chromatography (GC) allowed the separation of individual terpenes (Clements, 1958). GC is an analytical chemistry technique that separates compounds based on their volatility. This is done by heating a sample until it volatizes and then it is carried with an inert gas, such as nitrogen or helium, through a long column. In this column, more volatile compounds move faster and less volatile compounds fall behind. GC must be paired with a detector, such as a mass spectrometer (MS) to identify and quantify analytes. For the MS used in this work, compounds are bombarded with electrons resulting in ionization and fragmentation of the analytes. An electromagnetic field is used to filter ions based on their ionic mass to charge ratio $(\mathrm{m} / \mathrm{z})$. A microchannel plate detector then counts each ion and the data is collected in computer memory. The software generates a plot of relative abundance vs. $\mathrm{m} / \mathrm{z}$ for each ion in the sample, called a mass spectrum.

As compounds leave the the column, a peak is recorded on the chromatogram. The location of these peaks is used to determine retention time, or the time it took a compound to pass through the column. Peak size corresponds to relative concentration of the compounds in the sample. The National Institute of Standards and Technology 
(NIST) maintains a library of mass spectral data, which serves as a reference for the samples. A mass spectral match allows for the tentative identification of the compounds in a sample. Positive identification is achieved through the comparison to chromatographic results from authentic standards.

A limitation to traditional GC methods is that some compounds can co-elute, i.e. leave the column at the exact same time, resulting in unresolved peaks on the chromatogram. When this happens, compounds with the same or similar mass spectra, such as terpenes, can become indistinguishable.

Two-dimensional gas chromatography coupled with time-of-flight mass spectrometry $(\mathrm{GC} \times \mathrm{GC} / \mathrm{TOFMS})$ is a powerful analytical technique that is being developed for use in atmospheric chemistry by a research group at Portland State University (PSU). This research group is led by Drs. James Pankow, Wentai Luo, and Kelley Barsanti; and for the work presented herein, includes collaboration with Dr. Todd Rosenstiel and the efforts of Master's student Melissa Roskamp. Developed in the 1990s, GCxGC has only very recently been used to study VOCs in the atmosphere (Hamilton, 2010). The PSU Research Group is exploring GC $\times \mathrm{GC}$ capabilities in measuring individual tepenoids and thus advancing the state-of-knowledge regarding BVOCs and SOA formation.

$\mathrm{GC} \times \mathrm{GC}$ allows for the separation of a sample in two, independent columns of different polarities. Between the two columns, a modulator briefly focuses and releases analytes and column effluent, providing a two-dimensional chromatographic process (Figure 1). This process allows for the separation of compounds based on both relative volatility and 
relative polarity. Even terpene isomers with similar structures can be completely separated using $\mathrm{GC} \times \mathrm{GC}$. The use of two columns also allows for increased peak capacity and enhanced separation of many compounds which co-elute in the first dimension (Murray, 2012). GC×GC has proven effective for both targeted and nontargeted analysis of VOCs in the atmosphere (Hamilton, 2010 and references therein).

In this work, samples were collected during two field national campaigns and analyzed for BVOCs and their oxidation products using $\mathrm{GC} \times \mathrm{GC} / \mathrm{TOFMS}$. The first campaign, which took place in Colorado, was the Bio-hydro-atmosphere interactions of Energy, Aerosols, Carbon, $\mathrm{H}_{2} \mathrm{O}$, Organics and Nitrogen - Rocky Mountain Biogenic Aerosol Study (BEACHON-RoMBAS). The second, conducted in Missouri, was the Particle Investigations at a Northern Ozarks Tower: $\mathrm{NO}_{\mathrm{x}}$, Oxidant, Isoprene Research (PINOT NOIR) Study. During both campaigns, researchers from the National Center for Atmospheric Research (NCAR) operated a proton-transfer reaction time-of-flight mass spectrometer (PTR-TOF-MS) which will allow for validation and comparison of the GC $\times \mathrm{GC} / \mathrm{TOFMS}$ results presented here. 

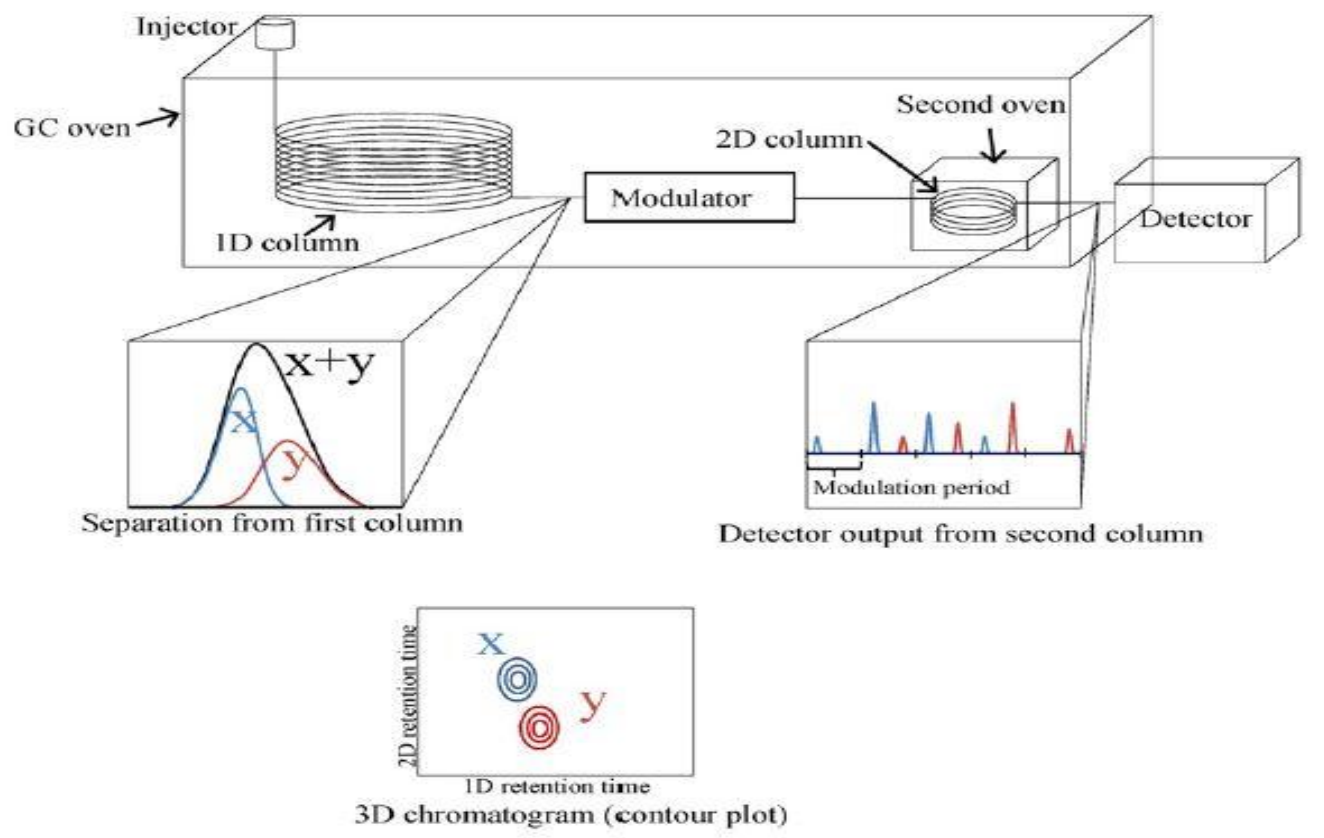

Figure 1: Reprinted from Murray, 2012 in accordance with the publisher's guidelines: Schematic of components of GCX GC and the separation after the first and second columns. After separation on the 1D column, analytes $x$ and $y$ are co-eluting. The modulator takes small fractions from the first column and injects them into the second column where analytes $x$ and $y$ have different retentions. The detector records the modulated peaks eluting from the 2D column. The output from the detector is then processed into a 3D chromatogram (shown as a contour plot in the figure).

More than 25 institutions participated in both field campaigns, including NCAR, the University of Innsbruck, University of California Berkley and the US EPA. The main objectives of both campaigns were to measure primary particles and SOA precursors, and to gain understanding of their transformation, and affects upon, the atmosphere. An important component of the BEACHON-RoMBAS campaign was the study of water availability: 1) to plants in affecting their emissions and, 2) in the atmosphere in affecting transformations of emitted compounds. The PINOT NOIR campaign provided a unique opportunity to conduct a large scale study during a time of intense plant stress caused by drought. The PSU Research Group participated in both campaigns in an effort to 
characterize BVOCs and their oxidation products in locations with differing plant compositions and with differing ambient conditions. 


\section{Site Descriptions}

\section{BEACHON-RoMBAS}

The Bio-hydro-atmosphere interactions of Energy, Aerosols, Carbon, $\mathrm{H}_{2} \mathrm{O}$, Organics and Nitrogen - Rocky Mountain Biogenic Aerosol Study (BEACHON-RoMBAS) campaign took place in July and August 2011 at the Manitou Forest Observatory $\left(39^{\circ} 06^{\prime} 02^{\prime}\right.$ 'N, $105^{\circ} 06^{\prime} 05^{\prime}$ 'W). Operated by the US Forest Service, the Manitou Forest Observatory is located about $40 \mathrm{~km}$ northwest of Colorado Springs, $\mathrm{CO}$ (Figure 2).

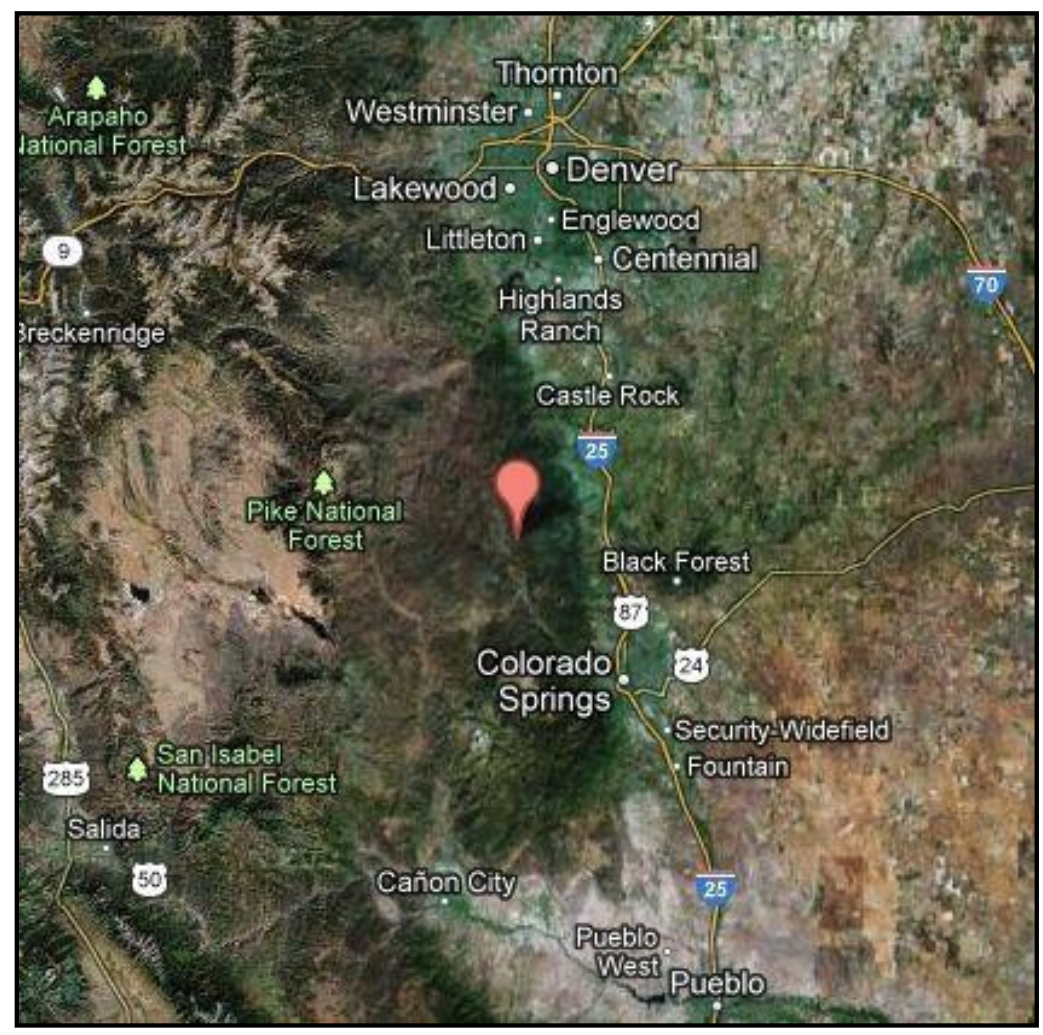

Figure 2: Google Earth image of the Manitou Experimental Forest of the Pike National Forest in Colorado, USA. The field site is indicated with a pin. 
The Manitou Experimental Forest has been described elsewhere in detail (Kim et al., 2010; Fry et al., 2013) and is characterized by high biogenic emissions and occasional anthropogenic incursions. Vegetation is almost entirely open-canopy Ponderosa pine $(P$. ponderosa), but also includes Douglas fir, oak, aspen and grasses. There is minimal undergrowth with a landscape averaged Leaf Area Index (LAI) of $1.9 \mathrm{~m}^{2} \mathrm{~m}^{-2}$ and a canopy height of $\sim 18.5 \mathrm{~m}$. During the campaign, thermally-driven mountain airflow patterns resulted in the transport of relatively clean air masses from the Southwest during the day and upslope transport from the Northwest of more polluted air (as evidenced by $\mathrm{NO}_{2}$ concentrations) during the nighttime (Fry et al., 2013). Rainfall events and high relative humidity - $35 \%$ (day) to $90 \%$ (night) — also took place during sampling. The dominant VOC concentrations were 2-methyl-3-butene-2-ol (MBO) during daytime and monoterpenes at night (Kim et al., 2010). A 30m instrumented tower was located in the center of the site to collect meteorological and trace gas measurements, including $\mathrm{O}_{3}$ and nitrogen oxides $\left(\mathrm{NO}_{\mathrm{x}}\right)$. To collect leaf-level emissions data, sampling enclosures were constructed around branches of the dominant plant species. For the BEACHONRoMBAS campaign, the PSU Research Group was not involved in the actual collection of samples; samples were collected by students and scientists from NCAR. Samples were run by Dr. Luo at PSU and the data analyzed by M. Roskamp. 


\section{PINOT NOIR}

The Particle Investigations at a Northern Ozarks Tower: $\mathrm{NO}_{\mathrm{x}}$, Oxidant, Isoprene

Research (PINOR NOIR) Study took place May-October 2012 in the Baskett Research and Education Area $\left(38^{\circ} 44^{\prime} 24^{\prime \prime} \mathrm{N}, 92^{\circ} 12^{\prime} 00^{\prime \prime} \mathrm{W}\right)$. Operated by the University of Missouri, the field site is located $10 \mathrm{~km}$ east of Ashland, MO (Figure 3).

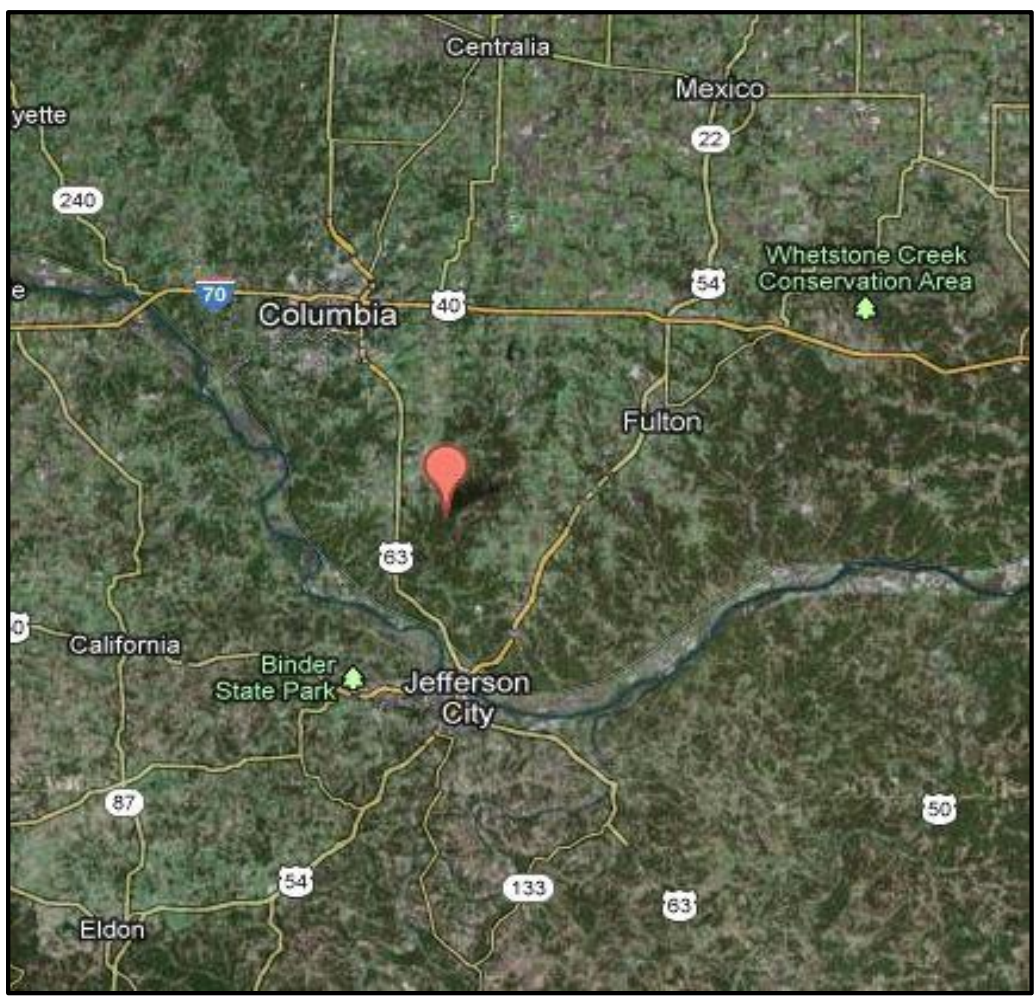

Figure 3: Google Earth image of the Baskett Research and Education Area in Missouri, USA. The field site is indicated with a pin. 
The Baskett Research and Education Area is located in the Ozark border region of southcentral Missouri where hardwood forest transitions to grassland. Vegetation at the site is predominantly oak (Quercus velutina, Q. alba, Q. rubra) and hickory (Carya spp.).

Previous studies in the region have shown that isoprene is the dominant VOC

(Wiedinmyer et al., 2005). Average canopy height is $17-20 \mathrm{~m}$ with an LAI of $4.2 \mathrm{~m}^{2} \mathrm{~m}^{-2}$. A $32 \mathrm{~m}$ instrumented tower was located on the site, as well as an instrumented trailer operated by the EPA to collect trace gas and meteorological data.

During most of 2012, the Midwestern United States experienced rainfall amounts that were significantly below average. During the PINOT NOIR campaign the Baskett Research and Education Area, as well as approximately $71 \%$ of the state, was classified as a D3 or "Extreme Drought" region by the National Oceanographic and Atmospheric Administration (NOAA) (Gustin, 2012). These conditions provided the opportunity to sample in a region where plants were experiencing climate and water stress, which can impact their emissions (Purves et al., 2004; Guenther et al., 2006). All samples were collected by M. Roskamp during the week of July $28^{\text {th }}$-August $3^{\text {rd }}, 2012$; the samples were run and analyzed at PSU by M. Roskamp. 


\section{Methods}

\section{Samples}

Offline, in-situ, gas-phase samples were collected during both BEACHON-RoMBAS and PINOT NOIR. Ambient air, above-canopy relaxed eddy accumulation (REA), and leaflevel samples were all collected, however leaf level samples were not analyzed as part of this work. REA is a sampling technique used for the measurement of micrometeorological fluxes of atmospheric species (Businger and Oncley, 1990; Ren et al., 2011). The REA was located at a height of $25 \mathrm{~m}$ on the instrumented towers at both sites. Anemometers within the REA detected the flux direction in the canopy (net up, down or neutral) and samples were collected for up and down fluxes within 30 minute periods. Ambient samples were collected from a height of 3-4 m within the tree canopy (Figures 4 and 5). Ambient samples were collected by drawing $3 \mathrm{~L}$ of air through an approximately $5 \mathrm{~m}$ Teflon® line with a portable SKC Aircheck Sampler, model 224PCXR8 (SKC, Eight Four, PA). 
Dominant Plant Species: $p$. ponderosa

Dominant Daytime Emission: MBO (Harley et al., 1998)

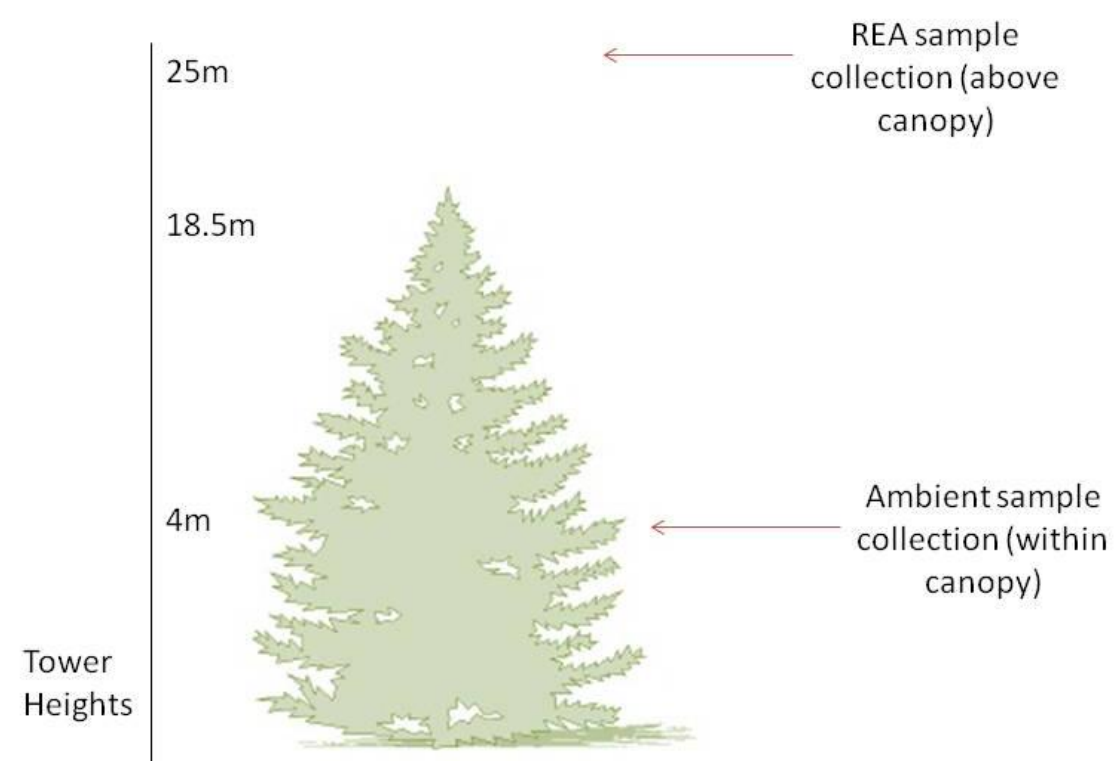

Figure 4: Schematic of sample collection with respect to the tree canopy during the BEACHON-RoMBAS campaign. Figure is not drawn to scale.

Dominant Plant Species: Quercus spp.

Dominant Daytime Emission: Isoprene (Quercus

virginiana, Tingey et al., 2006)

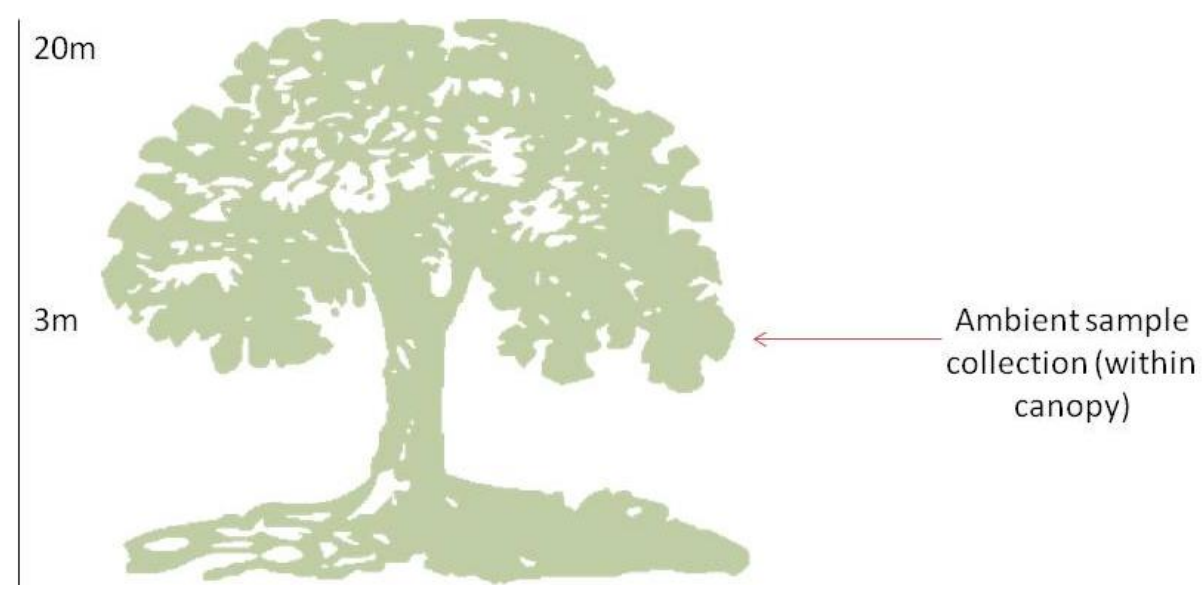

Figure 5: Schematic of sample collection with respect to the tree canopy during the PINOT NOIR campaign. Figure is not drawn to scale. 
During BEACHON-RoMBAS, a series of eight samples were collected over a 24-hour period on August $15-16^{\text {th }}, 2011$. In addition, three pairs (up/down) of REA samples were collected on August 11, 2011 (Appendix A). During PINOT NOIR, samples were collected three times per day, at approximately the same times, over a six day period (July $29^{\text {th }}$-August 3,2012 ); all samples were collected in duplicate (Figure 6). During the PINOT NOIR campaign, the sampling inlet for ambient samples was co-located with the inlet of the PTR-TOF-MS operated by researchers from NCAR. In addition, leaf-level cuvette samples and REA samples were also collected by NCAR (Appendix B).

During sample collection, air was passed through a potassium iodide or sodium thiosulfate coated glass-fiber filter to remove particles and scavenge oxidants (Figures 6 and 12). Terpenes are readily oxidized by $\mathrm{O}_{3}, \mathrm{OH}$ and $\mathrm{NO}_{3}$ and can have lifetimes as short as a few minutes (Atkinson and Arey, 2003). Significant losses of BVOCs to oxidation have been reported when sampling on sorbent beds (Arnts, 2008 and references therein). To prevent these losses, oxidants must be removed from the air stream prior to concentration on the cartridge (Cao and Hewitt, 1994; Calogirou et al., 1996). The potassium iodide or sodium thiosulfate filter coating reacts with $\mathrm{O}_{3}$ and other oxidants to remove them from the airstream. Without the use of an oxidant filter, Calogirou et al.(1996) found that un-saturated terpenes with one double bond (e.g. $\alpha$-pinene, sabinene) exhibited moderate losses $(5-35 \%)$ due to $\mathrm{O}_{3}$, and those with two or more double bonds (e.g. (E)-ocimene, $\beta$-caryophyllene) showed losses of 80-100\%. A variety of techniques have been developed for oxidant removal but few are commercially available (Helmig, 1996) and each with its own advantages and limitations. NCAR provided potassium 
iodide impregnated glass-fiber filters during sampling at BEACHON-RoMBAS. Due to concerns about potential reactions between sampled BVOCS and iodine, the PSU Research group chose to develop a different filter type during the PINOT NOIR study (based on Helmig, 1996). As described in Appendix C, commercially available glass fiber filters were coated with sodium thiosulfate and, prior to field deployment, were tested for their $\mathrm{O}_{3}$ removal capacity.

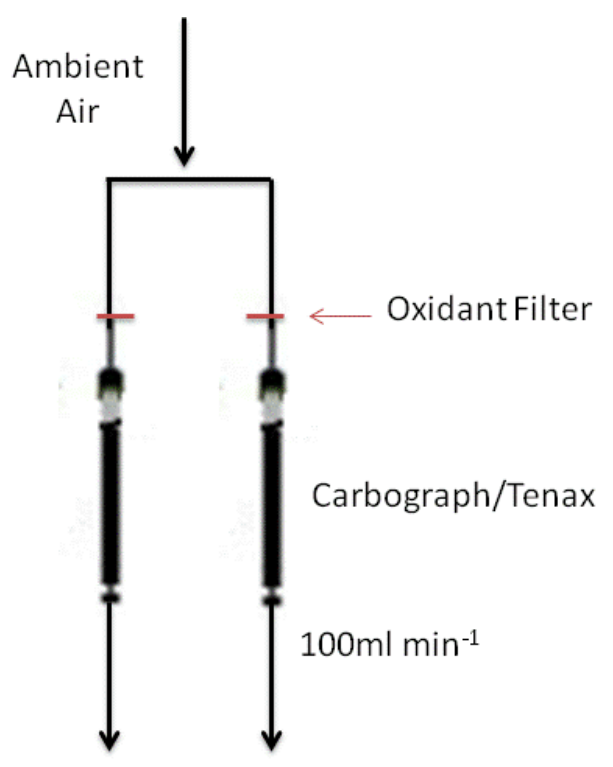

Figure 6: Schematic of ambient sample collection used during the PINOT NOIR campaign.

All samples were collected onto stainless steel, 0.25 inch O.D.×3.5 inch, adsorption/ thermal desorption (ATD) cartridges. Cartridges contained a sequential bed of Tenax ${ }^{\circledR}$ TA and Carbograph ${ }^{\mathrm{TM}}$ 1TD, which allows for the collection of both highly volatile BVOCs (hemiterpenes) and less volatile monoterpenes and sesquiterpenes (Pankow et al., 2012). Prior to sampling, the cartridges were cleaned by heating for $1 \mathrm{hr}$ to $290{ }^{\circ} \mathrm{C}$ with a flow of $100 \mathrm{~mL} \mathrm{~min}^{-1}$ of ultra-pure helium and spiked with $25 \mathrm{ng}$ of a gas-phase 
fluorobenzene standard. Un-sampled cartridges were transported and handled in an identical manner to serve as field "blanks". Before and after sampling, cartridges were sealed with brass Swagelok® endcaps and pre-cleaned Teflon ${ }^{\circledR}$ ferrules.

After sampling, cartridges were shipped and stored at $10{ }^{\circ} \mathrm{C}$ until analyzed at PSU within two weeks of sample collection. This method of conditioning and storage has been shown by Greenberg et al. (1999) to preserve >95\% of high-volatility compounds.

Based on the analysis of the BEACHON RoMBAS samples (see Results and Discussions-BEACHON-RoMBAS), greater efforts were made by the PSU Research Group to account for moisture during sampling. Due to collection in high humidity (during a rain event) some BEACHON-RoMBAS samples contained significant water, which when desorbed during analysis, depressed the $\mathrm{GC} \times \mathrm{GC}$ signal. Furthermore, high humidity is known to affect breakthrough behavior of adsorbent materials (Dettmer and Engewald, 2002) and promote the degradation of analytes (Fastyn et al., 2005 and references therein). High humidity was a concern for the Ozarks study because morning relative humidity in Columbia, MO during the months of July and August typically is $>87 \%$ (NOAA, 2008). To remove most adsorbed water, all PINOT NOIR cartridges were purged with $500 \mathrm{~mL}$ of dry, ultra-pure helium after sampling. This method was shown by Fastyn et al. (2004) to adequately remove moisture and thus reduce the risk of analysis issues and/or sample degradation. During PINOT NOIR, tests for breakthrough during ambient sampling were also performed. 


\section{Instrumentation and Analysis}

All samples were desorbed using an ATD 400 thermal desorption apparatus (PerkinElmer, Waltham, MA) for analysis on the $\mathrm{GC} \times \mathrm{GC}$. Each cartridge was desorbed (270 ${ }^{\circ} \mathrm{C}, 10 \mathrm{~min}$ ) with $40 \mathrm{~mL} \mathrm{~min}^{-1}$ of helium and re-concentrated on a focusing trap (Tenax® TA, $\left.10{ }^{\circ} \mathrm{C}\right)$ within the ATD 400 . The focus trap was desorbed $\left(290{ }^{\circ} \mathrm{C}, 3 \mathrm{~min}\right)$ and the effluent passed through a heated fused silica transfer line $\left(240{ }^{\circ} \mathrm{C}\right)$ to the $\mathrm{GC}$ injector.

Samples were analyzed using a LECO Pegasus 4D GC×GC (LECO, St. Joseph

Michigan), for which there is a wide selection of commercially available columns. Columns vary in length, internal diameter, polarity and material of construction. The selection of both the primary and secondary columns is done with consideration for the type of compounds being determined. Additionally, the rate at which the GC oven is heated and the flow rate of the carrier gas both allow for some control over the separation of peaks in the chromatogram.

The GC $\times \mathrm{GC}$ is paired with a time-of-flight mass spectrometry (TOFMS) detector. Flow from the GC injector to the column occurred with a 10:1 split. The primary column chosen was a DB-VRX (Agilent, Santa Clara, CA) which has a low polarity stationary phase. For analysis of the BEACHON-RoMBAS data a $60 \mathrm{~m}$ column was used, and for PINOT NOIR a 30m column. The secondary column for both was a $1.5 \mathrm{~m}$ StabilWax (Restek, Bellefonte, PA) which has a polar stationary phase. Between the two field campaigns, some changes were made to the temperature program to enhance separation 
and allow for easier comparison to published results (Figure 7). Additional details of the GC/MS setup can be found in Table 1.

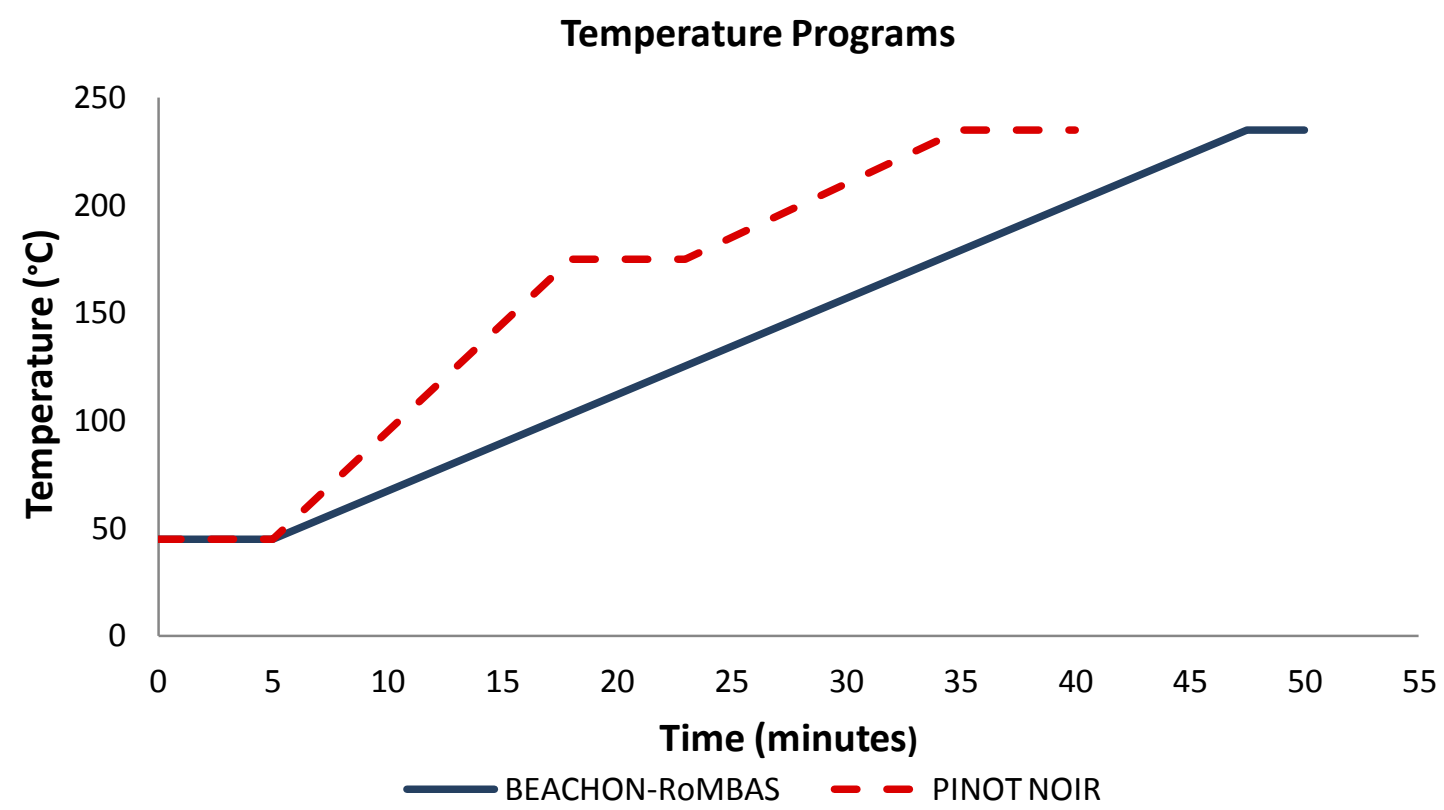

Figure 7: Temperature programs used for BEACHON-RoMBAS and PINOT NOIR data analysis.

Table 1: Summary of GC $\times$ GC/TOFMS conditions used for analysis of BEACHON-RoMBAS and PINOT NOIR samples.

\begin{tabular}{ll}
\hline GC injector & $225^{\circ} \mathrm{C}$, Split 10:1 (BEACHON) 5:1 (PINOT) \\
\hline Column flow & $1.2 \mathrm{~mL} / \mathrm{min}$ (mass flow controller) \\
\hline Primary column & Low polarity: DB-VRX, 60 m (BEACHON) or 30 m (PINOT), 0.25 \\
\hline $\mathrm{mm}$ I.D., $1.4 \mu \mathrm{m}$ film (Agilent, Santa Clara, CA)
\end{tabular}


Variations in the column set and conditions change compound retention times. Because the instrumental conditions (i.e., column length) differed between the two experiments, retention times therefore could not be directly related. In order to make comparisons between experiments, retention times were converted to system-independent constants called Kovats Retention Indices, RI (Murray, 2012). Kovats RI relate the order that each compound elutes relative to a series of straight chain alkanes, many of which are naturally present in air samples (Pankow et al., 2012). Using Equation 1, the first dimension retention index $I_{1, i}$ was calculated for each compound $i$ eluting at time $t_{1}, i$ between straight-chain alkanes of carbon length $j$ and $j+1$ (eluting at times $t_{1, j}$ and $t_{1, j+1}$ respectively). The theoretical straight-chain alkane eluting at the same first dimension retention time as compound $i$ is $n_{c, i}$.

$I_{1, i}=100\left[j+\frac{t_{1, i}+t_{1, j}}{t_{1, j+1}+t_{j}}\right]=100 n_{c, i}$

In the second dimension, column length dictates that retention times are only on the order of seconds and thus not long enough to calculate an index analogous to that of Equation 1 (Pankow et al., 2012). Instead, retention ratios were used to relate the second dimension retention time of a compound, $t_{2, i}$, to the second dimension retention time of the corresponding theoretical alkane, $n_{c, i}$ (Equation 2$)$. These theoretical alkanes typically do not have an integer carbon number.

$$
R_{2, i}=\frac{t_{2, i}}{t_{2, n_{c, i}}}
$$


The straight chained alkanes naturally present in the sample (typically $\mathrm{C}_{5}-\mathrm{C}_{19}$ ) were used to determine required values of $t_{2 n, c}$. Actual data pairs for these alkanes $\left(n_{c,} t_{2}\right)$ were plotted and a curve was fit to the data. Represented by a sixth order polynomial, this curve was used to determine retention times for the non-integer values of $n_{c, i}$.

\section{Data Processing}

Due to the increased peak capacity and the greater complexity of chromatograms generated by $\mathrm{GC} \times \mathrm{GC}$, computer software is needed for the analysis process. LECO ChromaTOF® software (Version 4.42) was used to organize, compare and classify the acquired data (LECO, 2012). During analysis, the software recorded the ratio of the atomic mass of an ion to its charge $(\mathrm{m} / \mathrm{z})$. The software then works to de-convolute the total ions in a chromatogram based on changes in the $m / z$. Peaks are then allocated to individual mass spectra, which are then tentatively identified. For this work, a minimum signal to noise ratio of 200 and a match similarity $>700$ with an NIST library mass spectrum were both required for inclusion in the LECO software peak tables. Using these criteria, a peak table for an ambient sample typically contained 1000-2000 entries. Even with the LECO software, automated identification in such complex samples is not possible and manual ion assignment and identification were often necessary. Data analysis steps are detailed in Appendix E. To further reduce the number of compounds, only entries with matches suggesting biogenic compounds - terpenoids and related compounds, plus their oxidation products-were analyzed in this work (Tables A6, A7). 
A mixture of 22 authentic BVOC compounds (Table A4, Appendix D) was also run to confirm NIST matches. Compounds found in the samples with a corresponding authentic standard were thus positively identified, whereas those without authentic standards were only tentatively indentified based on their spectra and published retention indices.

Quantification of compounds was achieved using response factors calculated from the BVOC standards (S) and the internal fluorobenzene standard (IS). A response factor relates the signal (peak area) produced from a compound to its mass based on the signal produced from a known mass of an internal standard (Equation 3).

$R F_{S}=\frac{\text { Area }_{S} / \text { Mass }_{S}}{\text { Area }_{I S} / \text { Mass }_{I S}}$

If the compound in the sample was one of those in the standard mixture, then the exact response factor was calculated and used. For compounds without standards, the average response factor of similar compounds was used (e.g. longifolene, $\mathrm{C}_{15} \mathrm{H}_{24}$, was quantified using an average of the response factors of the sesquiterpenes in the BVOC standard mixture). 


\section{Results and Discussions}

\section{BEACHON-RoMBAS}

More than 60 individual BVOCs were identified and quantified in samples using the GC $\times$ GC/TOFMS (Table A6). In agreement with previous findings, GC $\times$ GC/TOFMS data support that during the day, the predominant BVOC in the Manitou Experimental Forest is the hemiterpene $\mathrm{MBO}$, and during the night the predominant BVOCs are monoterpenes (Kim et al., 2010). MBO had the highest concentration of all BVOCs sampled, which is consistent with other measurements at the site (e.g. Kim et al., 2010) as well as emissions from Ponderosa pine (Harley et al., 1998).

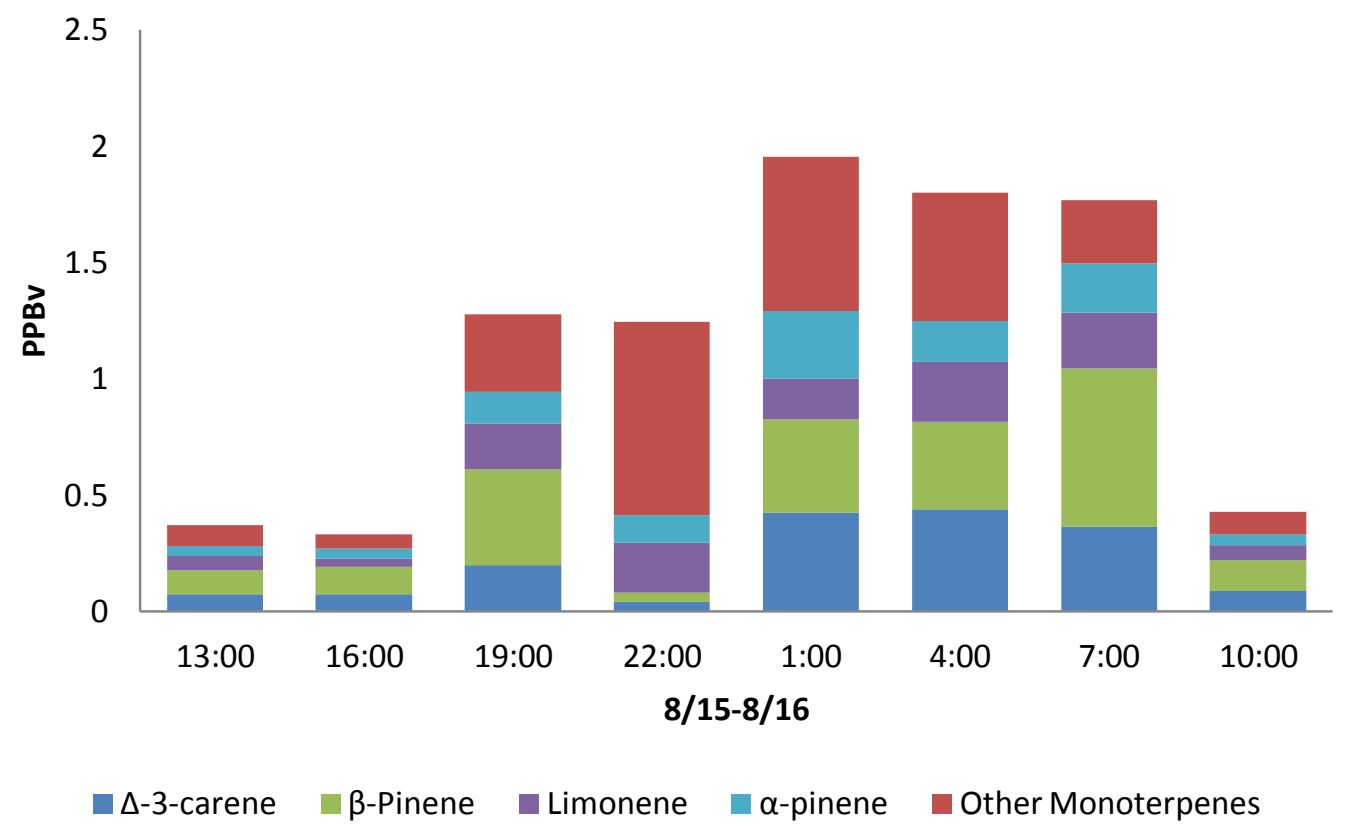

Figure 8: Column chart representing concentration of monoterpenes present in ambient samples during BEACHON-RoMBAS (including oxygenated monoterpenes). Concentrations of the four dominant monoterpenes are distinguished from the remaining monoterpene concentration. 
Previously published work has shown that the dominant monoterpenes at the site were $\Delta$ 3-carene, $\alpha$-pinene and $\beta$-pinene (Kim et al., 2010). GC $\times$ GC/TOFMS indicated that $\Delta$-3carene, $\beta$-pinene, $\alpha$-pinene and limonene were the dominant monoterpenes, with limonene concentrations often exceeding those of $\alpha$-pinene (Figure 8). Together, these four compounds accounted for $38 \%$ (night) to $87 \%$ (day) of the monoterpene concentration (Figure 9). The remaining mass can be attributed to small contributions from dozens of individual monoterpenes.

Daytime Monoterpene Distribution

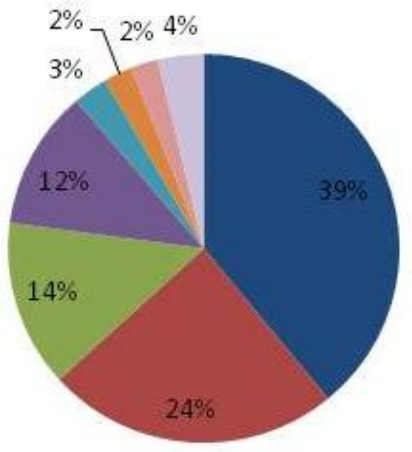
B-Pinene
$\triangle$-3-carene
a-Pinene
- Limonene
- $\beta$-Myrcene
Camphene
wamene
- Other Monoterpenes

Nighttime Monoterpene Distribution

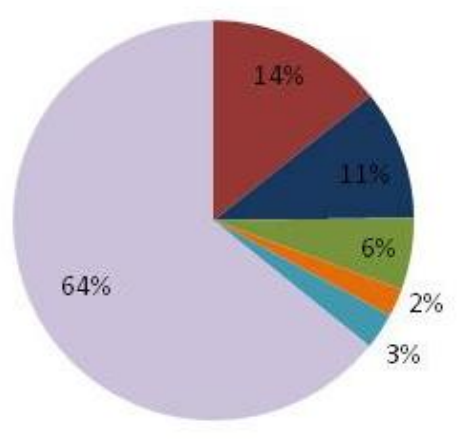
$\Delta-3$-carene
a-Pinene
- Limonene
Camphene
EC10H14 Isomer
w
Monoterpenes

Figure 9: Pie charts depicting the monoterpenes present in representative day and nighttime samples during BEACHON-ROMBAS. The daytime sample was collected at 16:00 on 8/15/11. The nighttime sample was collected at 1:00 on 8/16/11. 
BVOCs measured using GC $\times \mathrm{GC} / \mathrm{TOFMS}$ included hemiterpenes, monoterpenes, sesquiterpenes and oxygenated terpenes. Measured in all samples were directly emitted compounds - such as $\beta$-phellandrene $\left(\mathrm{C}_{10} \mathrm{H}_{16}\right)$, eucalyptol $\left(\mathrm{C}_{10} \mathrm{H}_{18} \mathrm{O}\right)$, and longifolene $\left(\mathrm{C}_{15} \mathrm{H}_{24}\right)$ - as well as compounds that are likely atmospheric oxidation products—such as methyl vinyl ketone $\left(\mathrm{C}_{4} \mathrm{H}_{6} \mathrm{O}\right)$ and $\mathrm{C}_{10} \mathrm{H}_{16} \mathrm{O}_{2}$ isomers. Some of the identified compounds, such as $\beta$-phellandrene and one of the monoterpene isomers, have the same first dimension retention index would have likely co-eluted using traditional GC techniques (Figure 10). Furthermore, twenty individual $\mathrm{C}_{10} \mathrm{H}_{16}$ monoterpenes were measured.

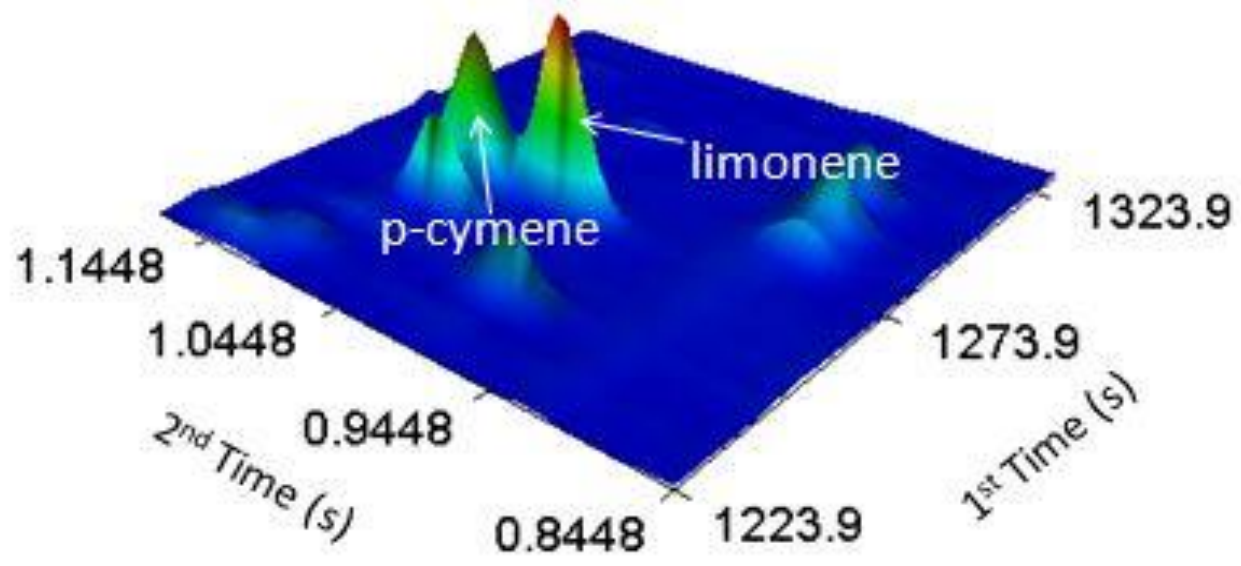

Figure 10: Chromatogram generated by GCXGC showing how the two labeled peaks, limonene and p-cymene would co-elute in the first dimension, but were adequately separated using GCXGC. 
A PTR-TOF-MS operated by NCAR measured a variety of VOCs during the BEACHON-RoMBAS campaign, including the first selective PTR-TOF-MS measurements of isoprene and MBO (Karl et al., 2012). Unfortunately, the PTR-TOFMS was not operating for the same 24-hour period in which the ambient samples presented here were collected. However, a comparison to data collected during another 24-hour period showed that total monoterpene concentrations followed the same diurnal pattern; the sum of all monoterpene concentrations were $\pm 20 \%$ between the two techniques. Relative to the monoterpenes, the isoprene/MBO concentration data matched less closely, but the PSU approach captured the same diurnal pattern as PTR-TOF-MS method. Nighttime isoprene/MBO measurements agreed well $( \pm 15 \%)$, but the reported PTR-TOF-MS average daytime peak concentrations were $\sim 50 \%$ larger than those seen in the $\mathrm{GC} \times \mathrm{GC}$ samples. By comparing to the selective isoprene and $\mathrm{MBO}$ concentrations reported, the discrepancy appears to be the result of poorly matched isoprene concentrations. Karl et al. reported a daytime isoprene/MBO ratio of $\sim 0.25$, whereas $\mathrm{GC} \times \mathrm{GC}$ measurements indicate a ratio of $<0.05$. While some discrepancy between daytime $\mathrm{MBO} /$ isoprene concentrations may have been due to differences in daytime meteorological conditions between the sampled days, this large discrepancy is evidence of sampling losses of the highest volatility compounds. Due to the high volatility of isoprene, breakthrough is a concern when sampling on sorbent cartridges, especially in humid conditions or in warm temperatures (Fastyn et al., 2005). During the night, when isoprene concentrations were lower and temperatures cooler, the cartridges were likely able to retain all or most of the sample. During the day, higher concentrations and warmer temperatures may have caused the overloading of active sites on the 
Carbograph $^{\mathrm{TM}}$ and isoprene breakthrough resulted. Because of this potential breakthrough, it was decided that isoprene breakthrough experiments would be conducted during the PINOT NOIR campaign.

$\mathrm{MBO}$ and isoprene measurements showed a direct correlation to temperature, indicative of the fact that MBO fluxes from Ponderosa pine are light and temperature dependant (Harley et al., 1998). The only measured monoterpene that appeared to exhibit any dependence on light or temperature was linalool $\left(\mathrm{C}_{10} \mathrm{H}_{18} \mathrm{O}\right)$. The measured linalool concentration was highest at midday and dropped to zero at night. Previous studies have shown that linalool emissions drop to zero, or near zero, at night (Straudt et al., 1997; Straudt et al., 2000). Branch enclosure measurements confirmed that the emissions of many monoterpenes and sesquiterpenes — except linalool and $\beta$-myrcene — did not exhibit any light dependency. Monoterpene concentrations were highest in nighttime ambient samples, an inverse trend to emissions measured in the branch enclosure system (Figure 11). This anti-correlation is likely due to the lowering of the boundary layer at night, which reduced the volume into which emissions were occurring; the same behavior was seen in the online PTR-TOF-MS samples and has been reported elsewhere (e.g. Harrison et al., 2001). This meteorological effect may conceal the light dependence of $\beta$ myrcene and makes it difficult to correlate measured ambient terpenes with emissions rates. Neither hemiterpene concentrations nor sesquiterpene concentrations exhibited the nighttime concentration increase seen in the monoterpene data. As discussed previously, the dominant hemiterpene, MBO, exhibits a strong light dependence in Ponderosa pine. Despite the lowering of the boundary layer, concentrations continued to decrease over the 
course of the night because emissions decreased while removal via transport and oxidation continued. Sesquiterpenes, remained at a consistent (very low) concentration despite the lowering of the boundary layer and continued emissions overnight, which was likely due to their rapid oxidation by nighttime $\mathrm{NO}_{3}$ (Atkinson and Arey, 2003).

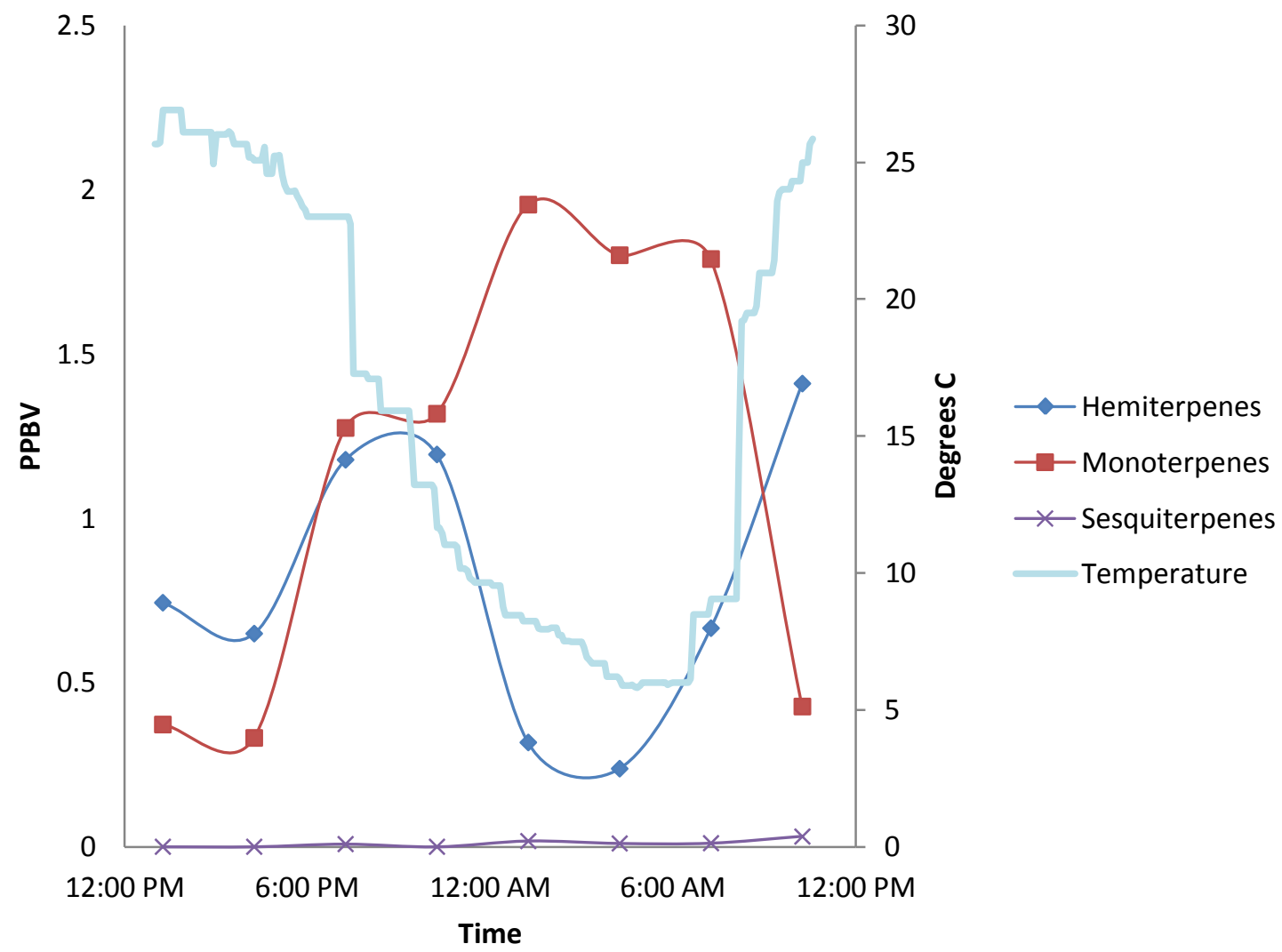

Figure 11: Diurnal concentrations of measured terpenes during BEACHON-RoMBAS. "Hemiterpenes" includes both MBO and isoprene; "Monoterpenes" includes monoterpenoids and oxygenated monoterpenes; "Sesquiterpenes" includes oxygenated sesquiterpenes.

Above canopy samples collected by the REA method contained the same monoterpenes as ambient samples, but sesquiterpenes and their oxidation products were not present. On average, total terpene concentrations in up fluxes were $>2 x$ the concentration in down fluxes. The absence of sesquiterpenes in REA samples is likely explained by losses in 
the canopy. Other studies have shown that highly reactive terpenes are often undetectable in above-canopy samples (Ciccioli et al., 1999). A canopy model developed by Stroud et al. (2005) suggested that only $30 \%$ of $\beta$-caryophyllene is able to escape the canopy. For this reason, enclosure samples are often used in conjunction with ambient sampling to better characterize emissions, especially for highly reactive compounds.

Enclosure samples collected at the site contained higher relative concentrations of linalool and sesquiterpenes than ambient or REA samples. Besides losses in the canopy, some of this discrepancy could be caused by losses on the impregnated potassium iodide filter. As noted in the introduction, removing oxidants, especially ozone, is critical to preserving monoterpenes in offline samples. Unfortunately, physical oxidant scrubbers/filters can cause losses of some terpenes, such as linalool and camphor (Calogirou, 1996 et al.; Helmig, 1997).

\section{PINOT NOIR}

\section{Series Sampling}

During the PINOT NOIR campaign, high levels of relative humidity $(\mathrm{RH})$ and high temperatures were anticipated. Tests for breakthrough were done by collecting ambient samples onto two cartridges, placed in series (Figure 12). A total of five experiments were conducted during regular sampling times throughout the week (Table 2).

Breakthrough of $\mathrm{C}_{4}-\mathrm{C}_{5}$ compounds was the greatest concern (Dettmer \& Engewald, 2002). Targeted $\mathrm{C}_{4}-\mathrm{C}_{5}$ compounds included isoprene, methacrolein and methyl vinyl ketone (MVK). To determine if, and how much, breakthrough occurred the masses of 
analytes on the back cartridge (minus blank levels) were compared to the masses of analytes on the front cartridge (minus blank levels).

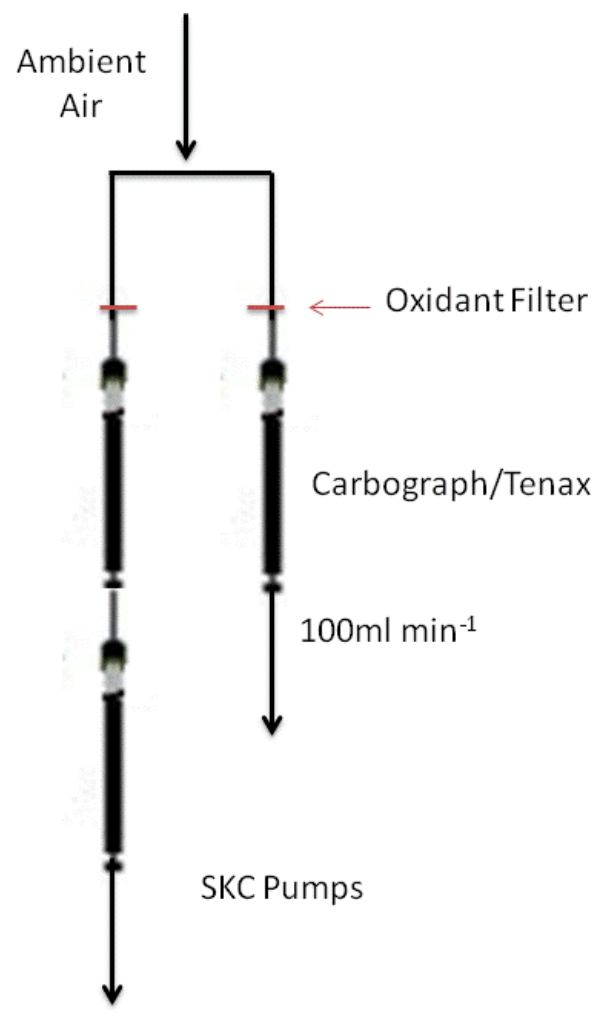

Figure 12: Sampling schematic for series samples collected during breakthrough experiments during the PINOT NOIR campaign. 
Table 2: Breakthrough experiments conducted during PINOT NOIR in which samples were collected onto two cartridges in series.

\begin{tabular}{ccccc}
$\begin{array}{c}\text { Experiment } \\
\text { Number }\end{array}$ & Date & Time & RH & Temp $\left({ }^{\circ} \mathbf{C}\right)$ \\
\hline 1 & 30-Jul & $11: 00$ & $56.20 \%$ & 30 \\
\hline 2 & 31-Jul & $11: 00$ & $43.60 \%$ & 32.2 \\
\hline 3 & 1-Aug & $11: 00$ & $43.60 \%$ & 32.5 \\
\hline 4 & 2-Aug & $14: 00$ & $53.20 \%$ & 30.7 \\
\hline 5 & 2-Aug & $15: 45$ & $49.70 \%$ & 31.4 \\
\hline
\end{tabular}

Due to the drought conditions in Missouri, humidity levels were not as high as is typical of July and August. During sample collection, RH levels typically exceeded 50\% and temperatures ranged from $25-41^{\circ} \mathrm{C}$. The results of the breakthrough experiments indicate that isoprene breakthrough was $\leq 20 \%$ and consistent with values published elsewhere (Figure 13). The breakthrough behavior of isoprene oxidation productsMVK and methacrolein-were more significant. MVK exhibited breakthroughs as high as $40 \%$ and concentrations and concentrations of methacrolein on the back cartridge exceeded those on the front (breakthrough >100\%). 


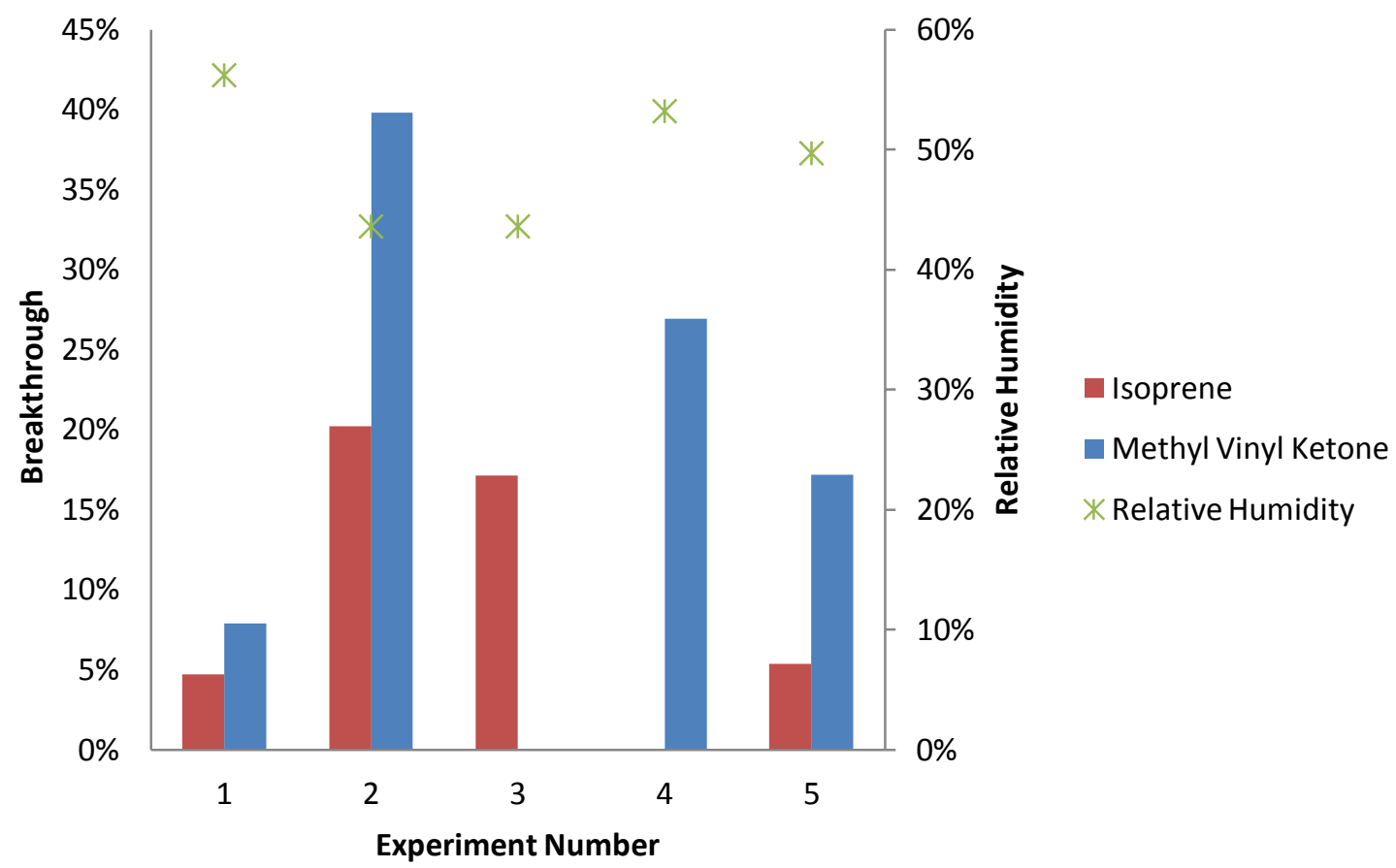

Figure 13: Results of the breakthrough experiments conducted during PINOT NOIR for both isoprene and methyl vinyl ketone.

No published information on specific retention volumes for MVK and methacrolein could be found in the literature. Pankow (1991) showed empirically that for organic compounds, specific breakthrough volume can be approximated for carbon sorbents using $\log p_{293}^{\circ}(\log$ vapor pressure at $293 \mathrm{~K})$ and boiling points. While no empirical fitting equation was derived for ketones or adehydes, using the $\log p^{\circ}{ }_{293}$ for MVK and methacrolein $\left(2.08\right.$ and 1.88 , respectively) and boiling points $\left(69^{\circ} \mathrm{C}\right.$ and $81{ }^{\circ} \mathrm{C}$, respectively) we could derive their relative retention volumes. Using this method, the specific retention volume of for MVK would be approximately $37 \%$ smaller than the retention volume of methacrolein. Based on this, it logical to assume that methacrolein should have been more fully retained than MVK and thus the significant difference in breakthrough of MVK versus methacrolein cannot be explained by retention behavior. 
Because there were no significant changes in temperature or VBOC concentration during the short sampling time, this indicates that rather than simply being poorly retained on the front cartridge, methacrolein was formed from isoprene between the two cartridges. Total MVK and methacrolein concentrations during the campaign are comparable to those measured with the PTR-TOF-MS (see PINOT NOIR Ambient Samples) so it is unlikely that methacrolein is a substantial artifact of single-cartridge sampling, like those used to collect ambient samples.

\section{Ambient Samples}

More than 150 BVOCs were measured in daytime ambient samples from the PINOT NOIR campaign (A7). Isoprene and its oxidation products-MVK and methacrolein $\left(\mathrm{C}_{4} \mathrm{H}_{6} \mathrm{O}\right)$ - were the dominant BVOCs. While attempts were made to measure leaf level and above canopy concentrations, those efforts were not fruitful and thus only ambient sampling is discussed in detail. Daytime measured isoprene concentrations were 4-10 ppbv, an order of magnitude larger than total monoterpene concentrations, and consistent with other measurements in the "Ozark Isoprene Volcano" (Wiedinmyer, 2005). These results were verified by PTR-TOF-MS measurements made by researchers from NCAR. Measured concentrations of isoprene and its oxidation products were comparable between the two instruments (Figures 14 and 15). 


\section{Measurements of Isoprene Oxidation Products}

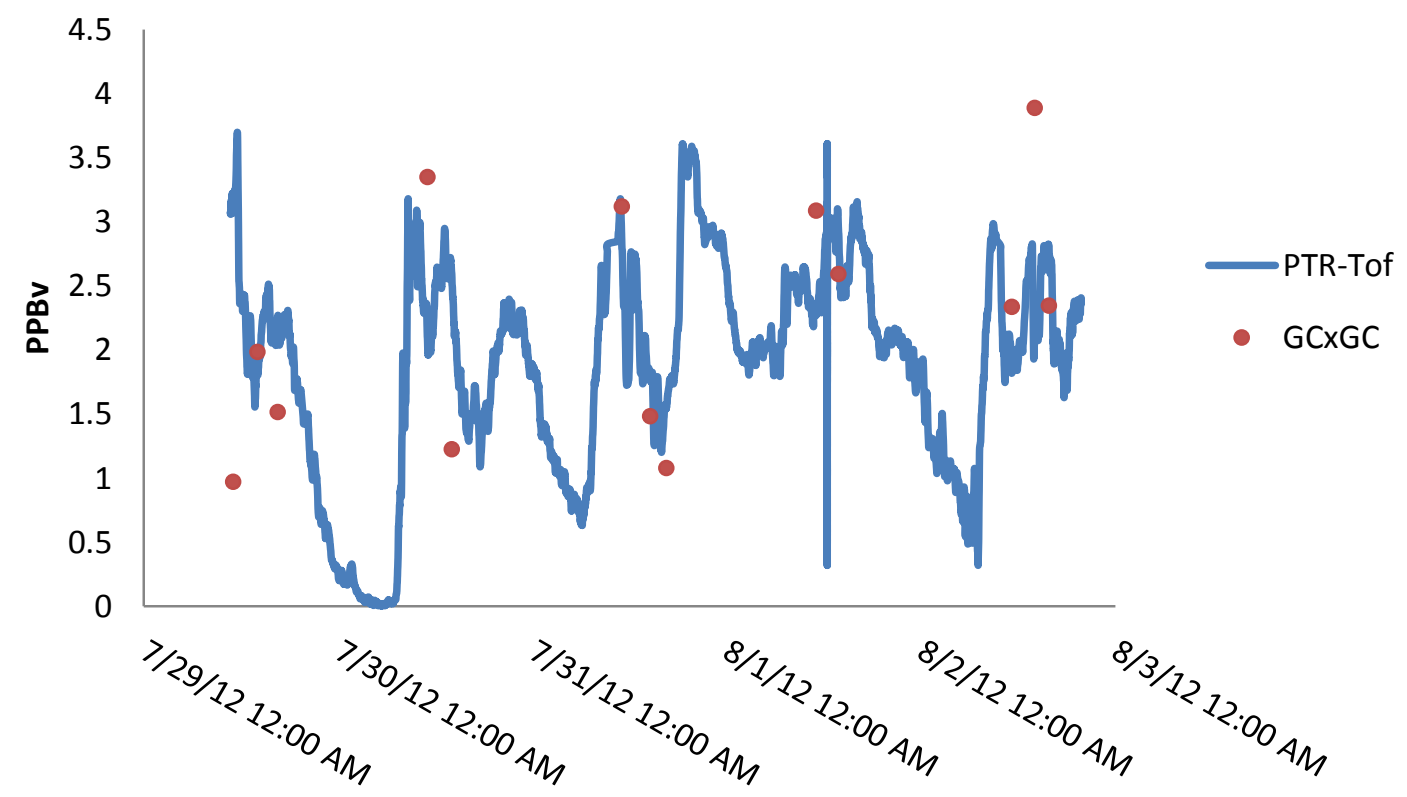

Figure 14: Comparison of summed methyl vinyl ketone + methacrolein concentrations measured using the GCXGC and the PTR-TOF-MS during PINOT NOIR. The GCXGC samples displayed here are highlighted in Table A2.

Both the PTR-TOF-MS and GCXGC captured the same temporal variations in the concentrations of isoprene and its oxidation products, with isoprene oxidation products typically peaking at midday. Isoprene concentrations were directly correlated with daytime temperatures, which is consistent with other published observations in the same temperature range (Rasulov et al., 2010). 


\section{Isoprene Measurements}

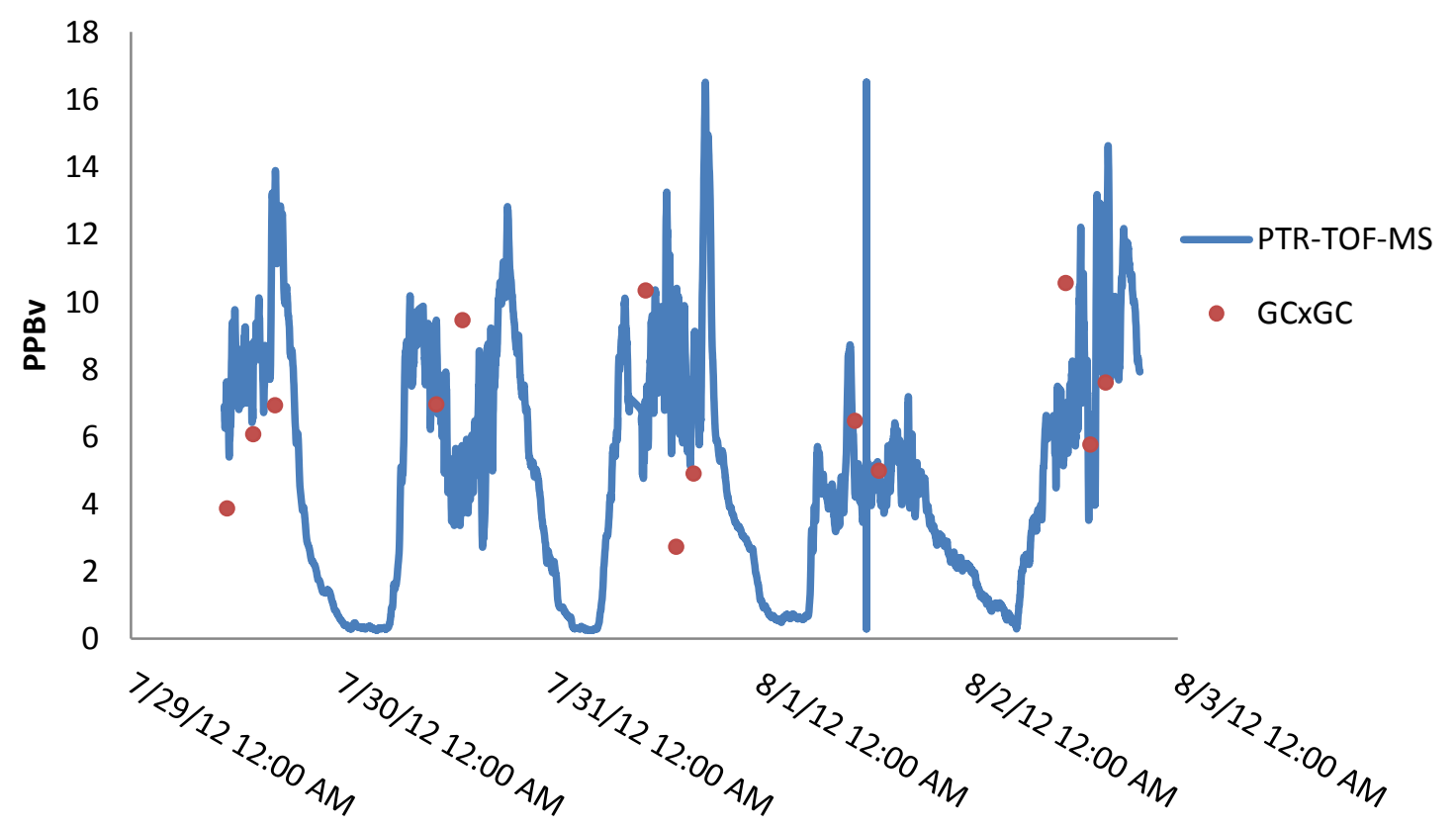

Figure 15: Comparison of isoprene concentrations measured using the GCXGC and the PTRTOF-MS during PINOT NOIR. The GCXGC samples displayed here are highlighted in Table A2.

Dominant monoterpene species measured at the site were limonene and sabinene.

Typically, $\alpha$ - and $\beta$-pinene are thought to account for $>50 \%$ of the total monoterpene concentration in the United States (Carlton and Baker, 2011 and references therein). While significant concentrations of $\alpha$-pinene were measured in each sample, $\beta$-pinene was only present in a small number of samples and accounted for less than $1 \%$ of the total monoterpene concentration. While total monoterpene concentration varied throughout the day, the composition of monoterpenes in samples did not change significantly (Figure 16). PTR-TOF-MS and GC $\times$ GC captured the same diurnal pattern in total monoterpene concentration, however samples analyzed with the GC $\times \mathrm{GC}$ contained higher concentrations of monoterpenes. The PTR-TOF-MS is only able to 
measure monoterpenes with a protonated $m / z$ of 137 (mass of $136, \mathrm{C}_{10} \mathrm{H}_{16}$ ). Even accounting for this by comparing only $\mathrm{C}_{10} \mathrm{H}_{16}$ compounds, the $\mathrm{GC} \times \mathrm{GC}$ still measured $2 \mathrm{x}$ that of the PTR-TOF-MS (Figure 17).

\section{Morning Monoterpene Distribution}
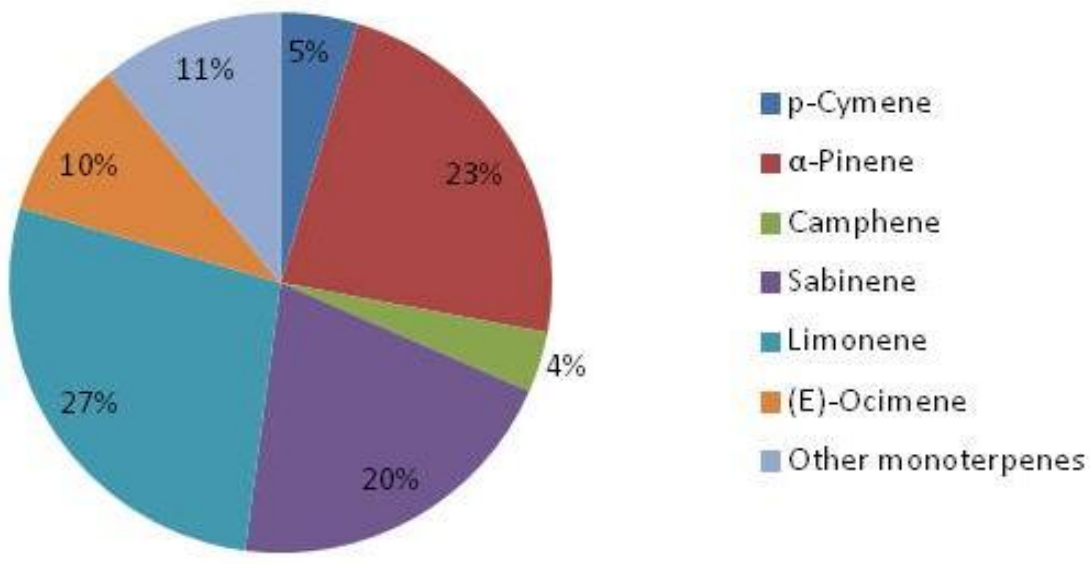

Afternoon Monoterpene Distribution

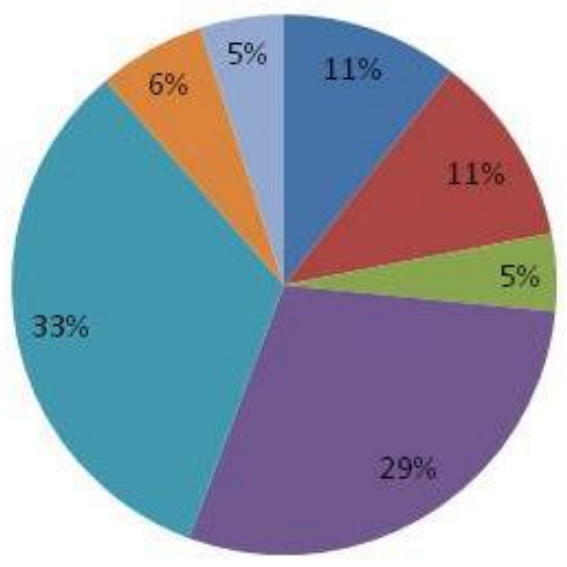

$$
\begin{aligned}
& \text { a-Cymene } \\
& \text { a-Pinene } \\
& \text { Camphene } \\
& \text { Sabinene } \\
& \text { Limonene } \\
& \text { (E)-Ocimene } \\
& \alpha \text {-Thujene }
\end{aligned}
$$

Figure 16: Pie charts depicting monoterpenes in a representative samples during the PINOT NOIR campaign. Oxygenated monoterpenes are not included. The morning sample was collected on $8 / 2 / 12$ at $11: 10$. The afternoon sample was collected $7 / 29 / 12$ at 14:00. 


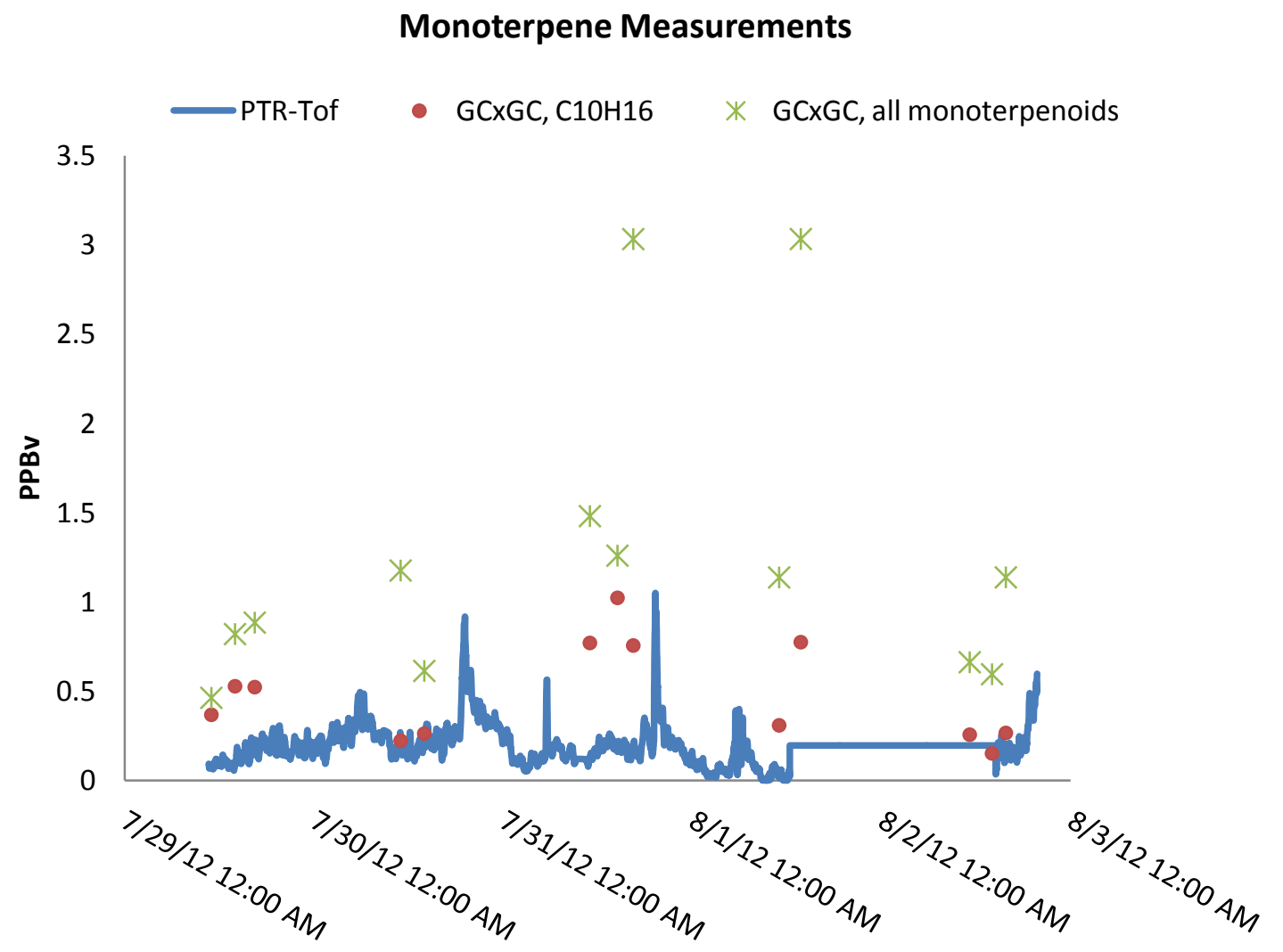

Figure 17: Comparison monoterpene concentrations measured using the GCXGC and the PTRTOF-MS during PINOT NOIR. Both the PTR-TOF-MS and the red GC $\times$ GC concentrations include only $\mathrm{C} 10 \mathrm{H} 16$ (MW 136) compounds. The green GCXGC concentrations also include monoterpenoids, such as p-cymene ( $\mathrm{C} 10 \mathrm{H} 12)$. No oxygenated monoterpenes are included in any concentrations. The GC×GC samples displayed here are highlighted in Table A2.

Because of the extreme heat and drought experienced at the sample site, additional standards were acquired and run to aid in the identification and quantification of any stress compounds potentially present in the samples (Table A5). These additional standards allowed for the positive identification of two ocimene isomers (E and Z- $\beta$ ocimene). Ocimene isomers are associated with plant stress (Guenther et al., 2012) and have been proposed to be some of the most significant monoterpenes in terms of global 
SOA production (Griffin et al., 1999). Like other monoterpene measurements, daytime ocimene concentrations were directly correlated to temperature.

High temperatures also allowed for the sampling of "semi-volatile" leaf surface compounds that are only expected to be found in the gas phase when leaf temperatures exceed $40{ }^{\circ} \mathrm{C}$ (Guenther et al., 2012). So called "sunscreen" compounds-homosalate $\left(\mathrm{C}_{16} \mathrm{H}_{22} \mathrm{O}_{3}\right)$ and octyl-salate $\left(\mathrm{C}_{15} \mathrm{H}_{22} \mathrm{O}_{3}\right)$-are typically found as a waxy coating on plant leaves to shield them from UV radiation. Both homosalate and octyl-salate were present in samples throughout the field campaign. Another semi-volatile compound, geranyl acetone $\left(\mathrm{C}_{13} \mathrm{H}_{22} \mathrm{O}\right)$, was also measured. Fruekilde et al. (1998) observed significant emissions of geranyl acetone when leaf surfaces were exposed to ozone. During sampling, daytime ozone concentrations exceeded $70 \mathrm{ppb}$. 


\section{Conclusions}

The PSU Research Group participated in two large-scale field campaigns in order to explore the potential role for two-dimensional gas chromatography coupled with time-offlight mass spectrometry (GC $\times$ GC/TOFMS) in advancing the understanding of ambient BVOCs important in air quality and climate. Previously, GC $\times$ GC has had only limited use in the study of atmospheric VOCs (Hamilton, 2010). This work represents some of the first analysis of ambient BVOCs with this technology, which is anticipated to contribute greatly to characterization of atmospheric SOA precursors and ultimately, to improve the modeling of SOA and fine particulate matter.

During the BEACHON-RoMBAS campaign, more than 60 BVOC species were identified and quantified. While monoterpene concentrations generally agreed with PTRTOF-MS results, it was demonstrated that the dominant monoterpenes detected at the site account for only $87 \%$ (day) and $38 \%$ (night) of total monoterpenes. These measurements provide corroboration to previous studies that BVOCs and their oxidation products are poorly characterized (Bouvier-Brown et al., 2009). This work demonstrated the potential for $\mathrm{GC} \times \mathrm{GC}$ to more fully characterize the identity of atmospheric BVOCs and suggests that a small number of individual monoterpenes make up a significant percentage of total monoterpenes, particularly during the nighttime. These findings have implications for predicting both $\mathrm{O}_{3}$ and SOA formation.

The potential of any individual BVOC to produce SOA is highly variable (Lee et al., 2006); it is demonstrated here that $\mathrm{GC} \times \mathrm{GC}$ can distinguish between compounds with the 
same $m / z$ and similar molecular structure. The PTR-TOF-MS and other chromatographic techniques are not able to make such distinctions. Furthermore, as lab and chamber studies advance the state of knowledge of SOA formation, the $\mathrm{GC} \times \mathrm{GC}$ can be used to detect atmospheric intermediates which show the oxidation pathway being undertaken in the atmosphere.

During the PINOT NOIR campaign measurements were made of over 150 BVOCs, including measurements of isoprene oxidation products (methyl vinyl ketone and methacrolein), stress compounds (ocimene) and semi-volatile leaf surface compounds (geranyl acetone). There are >1700 BVOCs known to be emitted by plants, and likely are others which have not been measured (Guenther et al., 2006). The ability of the GC $\times$ GC to perform non-targeted analysis (Murray, 2012), as particularly demonstrated for the PINOT-NOIR campaign, provides opportunities for compound discovery. The increased peak capacity and enhanced resolution of $\mathrm{GC} \times \mathrm{GC} / \mathrm{TOFMS}$ also allows for the detection of compounds that will be missed by other techniques, such as GC-MS or PTRTOF-MS. The potential to detect measured or undiscovered BVOCs will provide valuable information about the "missing mass" in the global carbon budget.

A better characterized profile of BVOCs will contribute not only to ongoing efforts to model future climate, but may also provide an indicator of climate-driven changes of the terrestrial ecosystem (Constable, et al., 1999), given that climate change is expected to increase BVOC emissions (Steiner et al., 2011) and changes in temperature and relative humidity will impact those emissions (Purves et al., 2004; Guenther et al., 2006). Climate change may contribute to heat or water stress in plants; as demonstrated in the 
PINOT NOIR samples, these stressors can change plant emissions profiles and result in the emission of highly reactive stress compounds.

Despite the demonstrated potential of $\mathrm{GC} \times \mathrm{GC}$, participation in both campaigns has also highlighted some of the future needs for $\mathrm{GC} \times \mathrm{GC}$ work, particularly: 1) the need for more authentic standards for positive identification of BVOCs and their oxidation products and, 2) a more efficient analysis software to mitigate the labor intensive analysis that is currently required. 


\section{References}

Arnts, R. R. Evaluation of adsorbent sampling tube materials and Tenax-TA for analysis of volatile biogenic organic compounds. Atmospheric Environment, 44, 1579-1584, 2010.

Atkinson, R. and Arey, J. Gas-phase tropospheric chemistry of biogenic volatile organic compounds: a review. Atmospheric Environment, 37, S197-S219.

Bouvier-Brown, N. C., Holzinger, R., Palitzsch, K., and Goldstein, A. H. Large emissions of sesquiterpenes and methyl chavicol quantified from branch enclosure measurements. Atmospheric Environment, 43(2), 389-401, 2009.

Barringer, F. Scientists Find New Dangers in Tiny but Pervasive Particles in Air Pollution. New York Times, Feb. 19, 2012. Print edition.

Businger, J. A., Oncley, S. P. Flux measurements with conditional sampling. Journal of Atmospheric and Oceanic Technology, 7, 349, 1989.

Cao, X. and Hewitt, C. N.: Study of the degradation by ozone of adsorbents and of hydrocarbons adsorbed ruing the passive sampling of air. Environmental Science and Technology, 28, 757-762, 1994.

Calogirou, A., Larson, B.R., Brussol, C., Duane, M. and Kotzias, D., Decomposition of Terpenes by Ozone during Sampling on Tenax. Journal of Analytical Chemistry, 68, 1499-1506, 1996.

Calogirou, A., Kotzias, D., Kettrup, A. Product analysis of the gas-phase reaction of $\beta$ caryophyllene with ozone. Atmospheric Environment, 31 (2), 283-285, 1997.

Carlton, A.G., Pinder, R. W., Bhave P.V. and Pouliot, G.A. To what extent can biogenic SOA be controlled? Environmental Science and Technology, 44, 3376-3380, 2010.

Carlton, A.G. and Baker, K.R. Photochemical Modeling of the Ozark Isoprene Volcano: MEGAN, BEIS, and Their Impacts on Air Quality Predictions. Environmental Science and Technology, 45(10), 4438-4445, 2011.

Clements, R.L. Low temperature chromatography as a means for separating terpene hydrocarbons. Science, 128(3329, 899-900, 1958.

Ciccioli, P., Brancaleoni, E., Frattoni, M., Di Palo, V., Valentini, R., Tirone, G., Seufert, G., Bertin, N., Hansen, U., Csiky, O., Lenz, R., Sharma, M. Emissions of reactive terpene compounds from orange orchards and their removal by within-canopy processes. Journal of Geophysical Research, 104, 8077-8094, 1999. 
Clean Air Act, 1990. Section 109. Accessed May 28, 2013 from Cornell University Law School: http://www.law.cornell.edu/uscode/text/42/7409

Constable, J., Guenther, A., Schimel, D., Monson, R. Modeling changes in VOC emission in response to climate change in the continental United States. Global Change Biology, 5, 791-806, 1999.

de Gouw, J. and Jimenez, J. L. Organic aerosols in the Earth's atmosphere. Environmental Science and Technology, 43(20), 7614-8, 2009.

de Gouw, J. A., Middlebrook, A. M., Warneke, C., Goldan, P. D., Kuster, W. C., Roberts, J. M., Fehsenfeld, F. C., Worsnop, D. R., Canagaratna, M. R., Pszenny, A. A. P., Keene, W. C., Marchewka, M., Bertman, S. B., and Bates, T. S. Budget of organic carbon in a polluted atmosphere: Results from the New England Air Quality Study in 2002. Journal of Geophysical Research, 110, 2005.

Dettmer, K., and Engewald, W. Adsorbent materials commonly used in air analysis for adsorptive enrichment and thermal desorption of volatile organic compounds. Analytical and bioanalytical chemistry, 373(6), 490-500, 2002.

Di Carlo et al. Missing OH reactivity in a forest: evidence for unknown reactive biogenic VOCs. Science, 304,722-725, 2004.

Ebi, K.L., McGregor, G. Climate change, tropospheric ozone and particulate matter, and health impacts. Environmental health perspectives, 116 (11), 1449-1455, 2008.

Fry, J. L., Draper, D. C., Zarzana, K. J., Campuzano-Jost, P., Day, D., Jimenez, J. L., Brown, S. S., et al. Observations of gas- and aerosol-phase organic nitrates at BEACHON-RoMBAS 2011. Atmospheric Chemistry and Physics Discuss., 13(1), 1979-2034, 2013.

Farmer, E.E. and Ryan, C.A. Interplant communication: airborne methyl jasmonate induces synthesis of proteinase inhibitors in plant leaves. Proceedings of the National Academy of Sciences USA, 87, 7713-7716, 1990.

Fastyn, P., Kornacki, W., Gierczak, T., Gawłowski, J., and Niedzielski, J.. Adsorption of water vapour from humid air by selected carbon adsorbents. Journal of Chromatography A, 1078(1-2), 7-12, 2005.

Fruekilde, P., Hjorth, J., Jensen, N.R., Kotzia, D., Larson, B. Ozonolysis at vegetation surfaces: A source of acetone, 4-oxopentanal, 6-methyl-5-hepten-2-one and geranyl acetone. Atmospheric Environment, 32, 1893-1902, 1998. 
Goldstein, A.H.and Galbally, I.E. Known and unexplored organic constituents in the earth's atmosphere. Environmental Science and Technology, 41, 1514-1521, 2007.

Greenberg, J. P., Guenther, A., Zimmerman, P., Baugh, W., Geron, C., Davis, K., Helmig, D., and Klinger, L. F.: Tethered balloon measurements of biogenic VOCs in the atmospheric boundary layer. Atmospheric Environment, 33, 855-867, 1999.

Guenther, A., Greenberg, J., Harley, P., Helmig, D., Klinger, L., Vierling, L., Zimmerman, P., and Geron, C.: Leaf, branch, stand, and landscape scale measurements of natural volatile organic compounds, Tree Physiology, 16, 17-24, 1996.

Guenther, A, Karl, T., Harley, P., Wiedinmyer, C., Palmer, P. I., and Geron, C. Estimates of global terrestrial isoprene emissions using MEGAN (Model of Emissions of Gases and Aerosols from Nature). Atmospheric Chemistry and Physics, 6, 31813210, 2006.

Guenther, A. B., Jiang, X., Heald, C. L., Sakulyanontvittaya, T., Duhl, T., Emmons, L.K., Wang, X. The Model of Emissions of Gases and Aerosols from Nature version 2.1 (MEGAN2.1): an extended and updated framework for modeling biogenic emissions. Geoscientific Model Development, 5, 1471-1492, 2012.

Gustin, G. 'Extreme' drought conditions grip most of Missouri. St. Louis Post-Dispatch, Aug. 3, 2012. Digital Edition.

Griffin, R.J., Cocker III, D.R., Seinfeld, J.H., Dabdub, D. Estimate of global atmospheric organic aerosol from biogenic hydrocarbons. Geophysical Research Letters, 26(17), 2721-2724, 1999.

Harley, P., Fridd-Stroud, V., Greenberg, J., Guenther, A., Vasconcellos, P. Emissions of 2-methyl-3-buten-2-ol by pines: A potentially large natural source of reactive carbon in the atmosphere. Journal of Geophysical Research, 203 (D19), 25479-25486, 1998.

Hamilton, J. Using comprehensive two-dimensional gas chromatography to study the atmosphere. Journal of Chromatographic Science, 48(4), 274-282, 2010.

Harrison, D., Hunter, M. C., Lewis, A. C., Seakins, P. W., Bonsang, B., Gros, V., Kanakidou, M., et al. Ambient isoprene and monoterpene concentrations in a Greek fir (Abies Borisii-regis) forest. Reconciliation with emissions measurements and effects on measured OH concentrations (1997). Atmospheric Environment, 35, 4699-4711, 2001. 
Heald, C. L., Jacob, D. J., Park, R. J., Russell, L. M., Huebert, B. J., Seinfeld, J. H., Liao, H., and Weber, R. J. A large organic aerosol source in the free troposphere missing from current models, Geophysical Research Letters, 32, 2005.

Helmig, D. Ozone removal techniques in the sampling of atmospheric volatile organic trace gases. Atmospheric Environment, 31, 3635-3651, 1997.

Intergovernmental Panel on Climate Change (IPCC): Climate Change 2007: The Physical Science Basis, Cambridge University Press, UK, 2007.

Karl, T., Hansel, A., Cappellin, L., Kaser, L., Hedlinger-Blatt, I., Jud, W. Selective measurements of isoprene and 2-methyl-3-buten-2-ol based on $\mathrm{NO}+$ ionization mass spectrometry. Atmospheric Chemistry and Physics, 12, 11877-11884, 2012.

Kim, S., Karl, T., Guenther, A., Tyndall, G., Orlando, J., Harley, P., Rasmussen, R., et al. Emissions and ambient distributions of Biogenic Volatile Organic Compounds (BVOC) in a ponderosa pine ecosystem : interpretation of PTR-MS mass spectra, (2004). Atmospheric Chemistry and Physics, 10, 1759-1771, 2010.

Kroll, J.H. and Seinfeld, J.H. Kroll, J. H., and Seinfeld, J. H. (2008). Chemistry of secondary organic aerosol: Formation and evolution of low-volatility organics in the atmosphere. Atmospheric Environment, 42(16), 3593-3624, 2008.

LECO ChromaTOF version 4.43; St. Joseph, Michigan. 2012

Lee, A., Goldstein, A. H., Kroll, J. H., Ng, N. L., Varutbangkul, V., Flagan, R. C., and Seinfeld, J. H. Gas-phase products and secondary aerosol yields from the photooxidation of 16 different terpenes. Journal of Geophysical Research, 111(D17), 2006.

Murray, J. Qualitative and quantitative approaches in comprehensive two-dimensional gas chromatography. Journal of Chromatographic Science, 1261, 58-68, 2012. Figure used in accordance with publisher copyright guidelines. www.stmassoc.org/2008_02_01_Guidelines_for_Quotation_From_Journal_Articles.pdf

Ng, N. L., Chhabra, P. S., Chan, a. W. H., Surratt, J. D., Kroll, J. H., Kwan, a. J., McCabe, D. C., et al.. Effect of NOx level on secondary organic aerosol (SOA) formation from the photooxidation of terpenes. Atmospheric Chemistry and Physics, 7, 5159-5174, 2007.

NOAA (2008, August). Retrieved May $29^{\text {th }}, 2013$ from National Climatic Data Center: http://www.ncdc.noaa.gov/oa/climate/online/ccd/avgrh.html 
Pankow, J.F. Gas phase retention volume behavior of organic compounds on Carbotrap graphitized carbon. Journal of Chromatographic Science, 547, 488-493, 1991.

Pankow, J. F. An absorption model of the gas model/aerosol partitioning involved in the formation of secondary organic. Atmospheric Environment, 28 (2), 189-193, 1994.

Pankow, J. F., Luo, W., Melnychenko, A. N., Barsanti, K. C., Isabelle, L. M., Chen, C., Guenther, A. B., et al. Volatilizable biogenic organic compounds (VBOCs) with two dimensional gas chromatography-time of flight mass spectrometry $(\mathrm{GC} \times \mathrm{GC}-$ TOFMS): sampling methods, VBOC complexity, and chromatographic retention data. Atmospheric Measurement Techniques, 5, 345-361, 2012.

Peñuelas, J. and Llusiá, J. The complexity of factors driving volatile organic compound emissions by plants. Biologia Plantarum, 44(4), 481-487, 2001.

Pollman, J., Ortega, J., and Helmig, D. Analysis of atmospheric sesquiterpenes: Sampling losses and mitigation of ozone interferences. Environmental Science and Technology, 39, 9620-9629, 2005.

Pope, C.A., and Dockery, D.W. Health Effects of Fine Particulate Air Pollution: Lines that Connect. Journal of the Air and Waste Management Association, 56, 709-742, 2006.

Purves, D.W., Caspersen J.P., Moorcroft P.R., Hurtt G.C., Pacala S.W. Human-induced changes in US biogenic volatile organic compound emissions: evidence from longterm forest inventory data. Global Change Biology, 10, 1737-1755, 2004.

Rasulov, B., Hüve, K., Bichele, I., Laisk, A., Niinemets, Ü. Temperature Response of Isoprene Emission in Vivo Reflects a Combined Effect of Substrate Limitations and Isoprene Synthase Activity: A Kinetic Analysis. Plant Physiology, 154(3), 15581570, 2010.

Ren, X., Sanders, J.E., Rajendran, A., Weber, R.J., Goldstein, A.H., Pusede, S.E., Browne, E.C., Min, K.E. and Cohen, R.C. A relaxed eddy accumulation system for measuring vertical fluxes of nitrous acid. Atmospheric Measurement Techniques, 4, 2093-2103, 2011.

Robinson, A., Grieshop, A., Donahue, N., Hunt, S. Updating the conceptual model for fine particle mass emissions from combustion systems. Journal of the Air and Waste Management Association, 60(10), 1204-1222, 2009.

Sheehan, P. and Bowman, F. Estimated effects of temperature of secondary organic aerosol concentrations. Environmental Science and Technology, 35(11), 2129-2135, 2001. 
Steiner, A. L., Tonse, S., Cohen, R. C., Goldstein, A. H. Harley, R. A. Influence of future climate and emissions on regional air quality in California, Journal of Geophysical Research, 111, 2006.

Straudt, M., Bertin, N., Hansen, U., Seufert, G., Ciccioli, P., Foster, P., Frenzel, B., and Fugit, J. Seasonal and diurnal patterns of monoterpene emissions from Pinus pinea (L.) under field conditions. Atmospheric Environment, 31, 145-156, 1997.

Straudt, M., Bertin, N., Frenzel, B., and Seufert, G. Seasonal variation in amount and composition of monoterpenes emitted by young Pinus pinea trees-Implications for emission modeling. Journal of Atmospheric Chemistry, 35, 77-99, 2000

Stroud, C., P. Makar, T. Karl, A. Guenther, C. Geron, A. Turnipseed, E. Nemitz, B. Baker, M. Potosnak, and Fuentes, J.D. Role of canopy-scale photochemistry in modifying biogenic-atmosphere exchange of reactive terpene species: Results from the CELTIC field study. Journal of Geophysical Research, 110, 2005.

Tingey, D. The Influence of Light and Temperature on Isoprene Emission Rates from Live Oak. Physiologia plantarum 47 (2), 112-118, 1979.

U.S. EPA. National Air Quality and Emissions Trends Report, 2003. Special Studies Report. EPA/R-03-005. http://www.epa.gov/air/airtrends/aqtrnd03/pdfs/chapter2crit.pdf

Wiedinmyer, C., et al. Ozarks Isoprene Experiment (OZIE): Measurements and modeling of the "isoprene volcano", Journal of Geophysical Research, 110, 2005.

Zhang, H., Surratt, J Lin, Y., Bapat, J., Kamens, R. Effect of relative humidity on SOA formation from isoprene/NO photooxidation: enhancement of 2-methylglyceric acid and its corresponding oligoesters under dry conditions. Atmospheric Chemistry and Physics, 11(13), 6411-6424, 2011.

Zhihui, W. A biogenic volatile organic compounds emission inventory for Beijing. Atmospheric Environment, 37(27), 3771-3782, 2003.

Zwenger, S., Basu, C. Plant terpenoids: applications and future potentials. Biotechnology and Molecular Biology Reviews, 3(1), 001-007, 2008. 


\section{Appendix A: Samples Collected During BEACHON-RoMBAS}

Table A1: Details of samples collected and analyzed during the BEACHON-RoMBAS campaign. "GC File Name" refers to the file in the LECO software.

\begin{tabular}{|c|c|c|c|c|c|c|}
\hline $\begin{array}{c}\text { Cartridge } \\
\#\end{array}$ & GC File Name & $\begin{array}{c}\text { Sample } \\
\text { Type }\end{array}$ & $\begin{array}{c}\text { Date } \\
\text { Collected }\end{array}$ & $\begin{array}{l}\text { Local } \\
\text { Time }\end{array}$ & $\begin{array}{c}\text { Sample } \\
\text { Time (min) }\end{array}$ & $\begin{array}{c}\text { Sample } \\
\text { Volume (L) }\end{array}$ \\
\hline 486 & VBOC20110927-33-2D:1 & Field Blank & - & $\mathrm{n} / \mathrm{a}$ & - & - \\
\hline 392 & VBOC20110927-07-2D:1 & REA 1-Down & $8 / 11 / 2011$ & 7:30 & 30 & 1.247 \\
\hline 735 & VBOC20110927-08-2D:1 & REA 1-Up & $8 / 11 / 2011$ & $7: 30$ & 30 & 3.433 \\
\hline 584 & VBOC20110927-02-2D:1 & REA 2-Up & $8 / 11 / 2011$ & 9:30 & 30 & 1.645 \\
\hline 601 & VBOC20110927-06-2D:1 & REA 2-Down & $8 / 11 / 2011$ & 9:30 & 30 & 3.118 \\
\hline 673 & VBOC20110927-04-2D:1 & REA 3-Down & $8 / 11 / 2011$ & $13: 30$ & 30 & 2.771 \\
\hline 685 & VBOC20110927-05-2D:1 & REA 3-Up & $8 / 11 / 2011$ & $13: 30$ & 30 & 1.530 \\
\hline 679 & VBOC20110927-03-2D:1 & REA 4-Up & $8 / 11 / 2011$ & $15: 30$ & 30 & 2.117 \\
\hline 357 & VBOC20110927-17-2D:1 & Ambient & $8 / 15 / 2011$ & $13: 00$ & 30 & 6.060 \\
\hline 619 & VBOC20110927-19-2D:1 & Ambient & $8 / 15 / 2011$ & $16: 00$ & 30 & 6.060 \\
\hline 654 & VBOC20110927-20-2D:1 & Ambient & $8 / 15 / 2011$ & $19: 00$ & 30 & 6.060 \\
\hline 545 & VBOC20110927-21-2D:1 & Ambient & $8 / 15 / 2011$ & $22: 00$ & 30 & 6.060 \\
\hline 320 & VBOC20110927-23-2D:1 & Ambient & $8 / 16 / 2011$ & 1:00 & 30 & 6.060 \\
\hline 590 & VBOC20110927-24-2D:1 & Ambient & $8 / 16 / 2011$ & 4:00 & 30 & 6.060 \\
\hline 730 & VBOC20110927-26-2D:1 & Ambient & $8 / 16 / 2011$ & $7: 00$ & 30 & 6.060 \\
\hline 534 & VBOC20110927-27-2D:1 & Ambient & $8 / 16 / 2011$ & $10: 00$ & 30 & 6.060 \\
\hline
\end{tabular}




\section{Appendix B: Samples collected during PINOT NOIR}

Table A2: Details of samples collected and analyzed during the PINOT NOIR campaign. "GC File Name" refers to the file in the LECO software. Highlighted samples are those used to generate ambient concentration figures shown in the body of the text.

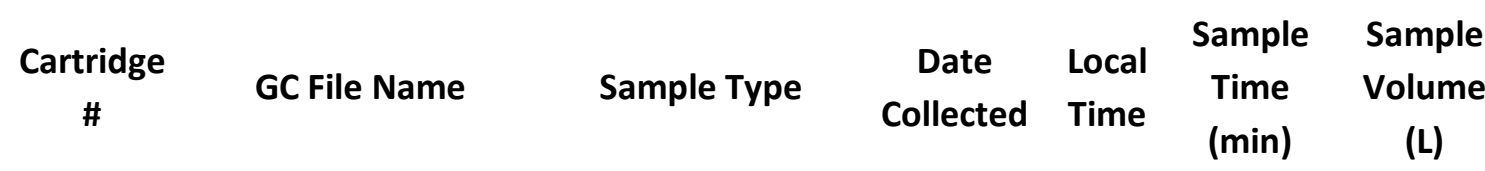

\begin{tabular}{|c|c|c|c|c|c|c|}
\hline 1048529 & VBOC2012091005-2D & Ambient & $7 / 29 / 2012$ & $11: 00$ & 30 & 3.000 \\
\hline 1048729 & VBOC2012091007-2D & Ambient & $7 / 29 / 2012$ & $11: 00$ & 30 & 3.000 \\
\hline 1048498 & VBOC2012090613-2D & Ambient & 7/29/2012 & $14: 00$ & 30 & 3.000 \\
\hline 1048590 & VBOC2012090702-2D & Ambient & $7 / 29 / 2012$ & $14: 00$ & 30 & 3.000 \\
\hline mi 136674 & VBOC2012091011-2D & Cuvette & $7 / 29 / 2012$ & $15: 00$ & 30 & 3.000 \\
\hline mi 141269 & VBOC2012091008-2D & Cuvette & $7 / 29 / 2012$ & $15: 00$ & 30 & 3.000 \\
\hline 1048735 & VBOC2012090614-2D & Ambient & $7 / 29 / 2012$ & $16: 30$ & 30 & 3.000 \\
\hline 1048294 & VBOC2012091003-2D & Ambient & 7/29/2012 & $16: 30$ & 30 & 3.000 \\
\hline a30071 & VBOC2012090704-2D & field blank (cuvette) & $7 / 29 / 2012$ & $\mathrm{n} / \mathrm{a}$ & - & - \\
\hline 1048743 & VBOC2012091002-2D & field blank & 7/29/2012 & $\mathrm{n} / \mathrm{a}$ & - & - \\
\hline 1048545 & VBOC2012090615-2D & Ambient & $7 / 30 / 2012$ & $11: 00$ & 30 & 3.000 \\
\hline 1048303 & VBOC2012091004-2D & Series 1 FRONT & $7 / 30 / 2012$ & $11: 00$ & 30 & 1.650 \\
\hline 1048670 & VBOC2012090616-2D & Series $1 \mathrm{BACK}$ & $7 / 30 / 2012$ & $11: 00$ & 30 & 1.650 \\
\hline 1048357 & VBOC2012090703-2D & Ambient & $7 / 30 / 2012$ & $14: 00$ & 30 & 3.000 \\
\hline 1048696 & VBOC2012091006-2D & Ambient & $7 / 30 / 2012$ & $14: 00$ & 30 & 3.000 \\
\hline 1048494 & VBOC2012090511-2D & field blank & $7 / 30 / 2012$ & $\mathrm{n} / \mathrm{a}$ & - & \\
\hline 1048270 & VBOC201203117-2D & Series 2 FRONT & $7 / 31 / 2012$ & $11: 00$ & 47 & 2.820 \\
\hline 1048392 & VBOC201203115-2D & Series 2 BACK & $7 / 31 / 2012$ & $11: 00$ & 47 & 2.820 \\
\hline
\end{tabular}




\begin{tabular}{|c|c|c|c|c|c|c|}
\hline mi 152483 & VBOC201203114-2D & Cuvette & 7/31/2012 & $13: 45$ & 30 & 3.000 \\
\hline 1048730 & VBOC20120830010-2D & Ambient & $7 / 31 / 2012$ & $14: 30$ & 30 & 3.000 \\
\hline 1048679 & VBOC2012090509-2D & Ambient & $7 / 31 / 2012$ & $14: 30$ & 30 & 3.000 \\
\hline mi 152531 & VBOC2012090512-2D & Cuvette & $7 / 31 / 2012$ & $14: 45$ & 30 & 3.000 \\
\hline 1048673 & VBOC201203113-2D & Ambient & $7 / 31 / 2012$ & $16: 30$ & 30 & 3.000 \\
\hline 1048339 & VBOC201203116-2D & Ambient & $7 / 31 / 2012$ & $16: 30$ & 30 & 3.000 \\
\hline A35989 & VBOC2012083006-2D & field blank (cuvette) & $7 / 31 / 2012$ & $\mathrm{n} / \mathrm{a}$ & - & - \\
\hline 1042060 & VBOC201203112-2D & field blank & $7 / 31 / 2012$ & $\mathrm{n} / \mathrm{a}$ & - & - \\
\hline 1048503 & VBOC20120830011-2D & Ambient & $8 / 1 / 2012$ & $11: 00$ & 30 & 3.000 \\
\hline 1048619 & VBOC201203109-2D & Series 3 FRONT & $8 / 1 / 2012$ & $11: 00$ & 50 & 2.500 \\
\hline 1048601 & VBOC201203103-2D & Series 3 BACK & $8 / 1 / 2012$ & $11: 00$ & 50 & 2.500 \\
\hline 1048475 & VBOC20120830013-2D & Ambient & 8/1/2012 & $13: 45$ & 30 & 3.000 \\
\hline 1048312 & VBOC201203108-2D & Ambient & $8 / 1 / 2012$ & $13: 45$ & 30 & 3.000 \\
\hline mi 152471 & VBOC201203106-2D & Cuvette & $8 / 1 / 2012$ & $14: 30$ & 30 & 3.000 \\
\hline mi 155809 & VBOC201203102-2D & Cuvette & $8 / 1 / 2012$ & $14: 30$ & 30 & 3.000 \\
\hline mi 124872 & VBOC201203105-2D & field blank (cuvette) & $8 / 1 / 2012$ & $\mathrm{n} / \mathrm{a}$ & - & - \\
\hline 1048587 & VBOC201203107-2D & field blank & $8 / 1 / 2012$ & $\mathrm{n} / \mathrm{a}$ & - & - \\
\hline 1048345 & VBOC2012090606-2D & Ambient & $8 / 2 / 2012$ & $11: 10$ & 30 & 3.000 \\
\hline 1048654 & VBOC2012090608-2D & Ambient & $8 / 2 / 2012$ & $11: 10$ & 30 & 3.000 \\
\hline mi 141207 & VBOC2012090506-2D & REA blank & $8 / 2 / 2012$ & $\mathrm{n} / \mathrm{a}$ & - & - \\
\hline 1048362 & VBOC2012090607-2D & field blank & $8 / 2 / 2012$ & $\mathrm{n} / \mathrm{a}$ & - & - \\
\hline mi 136758 & VBOC2012090601-2D & REA-1 down & $8 / 2 / 2012$ & $14: 00$ & 30 & 3.000 \\
\hline mi 136690 & VBOC2012090514-2D & REA--1 up & $8 / 2 / 2012$ & $14: 00$ & 30 & 3.000 \\
\hline
\end{tabular}




\begin{tabular}{|c|l|c|c|c|c|c|}
\hline 1048738 & VBOC2012090504-2D & Ambient & $8 / 2 / 2012$ & $14: 00$ & 30 & 3.000 \\
\hline 1048695 & VBOC2012090617-2D & Series 4 FRONT & $8 / 2 / 2012$ & $14: 00$ & 40 & 2.720 \\
\hline 1048685 & VBOC2012090612-2D & Series 4 BACK & $8 / 2 / 2012$ & $14: 00$ & 40 & 2.720 \\
\hline mi 155805 & VBOC2012090505-2D & REA--Neutral & $8 / 2 / 2012$ & $14: 00$ & 30 & 3.000 \\
\hline mi 152538 & VBOC2012090404-2D & REA--2 up & $8 / 2 / 2012$ & $14: 30$ & 30 & 3.000 \\
\hline mi 141265 & VBOC2012090508-2D & REA--2 down & $8 / 2 / 2012$ & $14: 30$ & 30 & 3.000 \\
\hline mi 141255 & VBOC2012090403-2D & REA--3 up & $8 / 2 / 2012$ & $15: 00$ & 30 & 3.000 \\
\hline mi 152469 & VBOC2012091009-2D & REA--3 down & $8 / 2 / 2012$ & $15: 30$ & 30 & 3.000 \\
\hline 1048464 & VBOC2012090611-2D & Ambient & $8 / 2 / 2012$ & $15: 45$ & 30 & 3.000 \\
\hline 1048701 & VBOC2012090609-2D & Series 5 FRONT & $8 / 2 / 2012$ & $15: 45$ & 43 & 2.924 \\
\hline 1048516 & VBOC2012090510-2D & Series 5 BACK & $8 / 2 / 2012$ & $15: 45$ & 43 & 2.924 \\
\hline 1048535 & VBOC2012090602-2D & field blank & $8 / 3 / 2012$ & $n / a$ & - & - \\
\hline 1048657 & VBOC2012090513-2D & Ambient & $8 / 3 / 2012$ & $11: 00$ & 30 & 3.000 \\
\hline 1048616 & VBOC2012090603-2D & Ambient & $8 / 3 / 2012$ & $11: 00$ & 30 & 3.000 \\
\hline
\end{tabular}




\section{Appendix C: Ozone Filters}

The filters chosen were Whatman GD/X syringe filters consisting of four layers glass fiber and membrane enclosed in a Teflon case. These filters were chosen because they are single use, eliminating the need to clean and dry the filter housing between samples (GE Healthcare, Piscataway, NJ)

Sodium thiosulfate and potassium iodide are the two most widely used chemicals for the sampling of BVOCs (Helmig, 1996). Due to concerns about iodine contamination, sodium thiosulfate was chosen.

Sodium thiosulfate neutralizes ozone through the reaction:

$2 \mathrm{NaS}_{2} \mathrm{O}_{3}+\mathrm{O}_{3}+2 \mathrm{H} \rightarrow \mathrm{S}_{4} \mathrm{O}_{6}+\mathrm{O}_{2}+\mathrm{H}_{2} \mathrm{O}$

A16 mg mL $\mathrm{mL}^{-1}$ solution was made by dissolving $\mathrm{Na}_{2} \mathrm{~S}_{2} \mathrm{O}_{3} \cdot 5 \mathrm{H}_{2} \mathrm{O}$ in Milli-Q water. Filters were saturated with this solution and then dried using ultra-pure helium while inside an $80{ }^{\circ} \mathrm{C}$ oven. After drying, each filter was weighed to ensure that it was coated in 2-3 mg of sodium thiosulfate - roughly 10x the necessary amount to remove the $75 \mathrm{ppb}$ ozone expected during sampling.

Three filters were tested in the lab using a Dasibi Model 1003-AH ozone generator. Due to design restrictions, the minimum ozone output from this generator ranged from 350 $550 \mathrm{ppb}$ at a flow of $300 \mathrm{~mL} \mathrm{~min}^{-1}$. Despite the fact that these conditions greatly exceeded those expected in the field, all filters managed $100 \%$ ozone removal for $>5$ minutes. And the results are summarized in Table A3.

Table A3: Results of ozone breakthrough experiment using $\mathrm{Na}_{2} \mathrm{~S}_{2} \mathrm{O}_{3}$ coated filters

\begin{tabular}{|c|c|c|c|}
\hline Filter Number & $\begin{array}{c}\text { Air Flow } \\
\left(\mathbf{m L ~ m i n}^{-1}\right)\end{array}$ & $\begin{array}{c}\text { Initial Ozone } \\
\text { Concentration (ppb) }\end{array}$ & $\begin{array}{c}\text { Time to } \\
\text { Breakthrough (min) }\end{array}$ \\
\hline 1 & 300 & 360 & 20 \\
\hline 2 & 300 & 430 & 6 \\
\hline 3 & 300 & 535 & 5.5 \\
\hline
\end{tabular}




\section{Appendix D: Authentic Standards Used in Analysis}

Table A4: Compounds included in BVOC standard mixture used for positive identification in BEACHON-RoMBAS and PINOT NOIR samples.

\begin{tabular}{lll}
\multicolumn{1}{c}{ Compound } & \multicolumn{1}{c}{ CAS } & Formula \\
\hline Isoprene & $78-79-5$ & $\mathrm{C} 5 \mathrm{H} 8$ \\
\hline 2-Methyl-3-buten-2-ol (MBO) & $115-18-4$ & $\mathrm{C} 5 \mathrm{H} 100$ \\
\hline$\alpha-$ Pinene & $80-56-8$ & $\mathrm{C} 10 \mathrm{H} 16$ \\
\hline Camphene & $79-92-5$ & $\mathrm{C} 10 \mathrm{H} 16$ \\
\hline$\beta-$ Myrcene & $123-35-3$ & $\mathrm{C} 10 \mathrm{H} 16$ \\
\hline$\beta$-Pinene & $127-91-3$ & $\mathrm{C} 10 \mathrm{H} 16$ \\
\hline$\alpha-$ Phellandrene & $99-83-2$ & $\mathrm{C} 10 \mathrm{H} 16$ \\
\hline$\Delta-3-$ Carene & $13466-78-9$ & $\mathrm{C} 10 \mathrm{H} 16$ \\
\hline Limonene & $138-86-3$ & $\mathrm{C} 10 \mathrm{H} 16$ \\
\hline p-Cymene & $527-84-4$ & $\mathrm{C} 10 \mathrm{H} 14$ \\
\hline Eucalyptol & $470-82-6$ & $\mathrm{C} 10 \mathrm{H} 180$ \\
\hline Terpinolene & $586-62-9$ & $\mathrm{C} 10 \mathrm{H} 16$ \\
\hline Linalool & $78-70-6$ & $\mathrm{C} 10 \mathrm{H} 180$ \\
\hline Nopinone & $24903-95-5$ & $\mathrm{C} 9 \mathrm{H} 140$ \\
\hline Camphor & $76-22-2$ & $\mathrm{C} 10 \mathrm{H} 160$ \\
\hline $4-T e r p i n e n o l$ & $562-74-3$ & $\mathrm{C} 10 \mathrm{H} 180$ \\
\hline Terpineol & $586-62-9$ & $\mathrm{C} 10 \mathrm{H} 180$ \\
\hline Estragole (methyl chavicol) & $140-67-0$ & $\mathrm{C} 10 \mathrm{H} 120$ \\
\hline$\alpha-$ Cedrene & $469-61-4$ & $\mathrm{C} 15 \mathrm{H} 24$ \\
\hline B-Caryophyllene & $87-44-5$ & $\mathrm{C} 15 \mathrm{H} 24$ \\
\hline Aromadendrene & $109119-91-7$ & $\mathrm{C} 15 \mathrm{H} 24$ \\
\hline Humulene & $6753-98-6$ & $\mathrm{C} 15 \mathrm{H} 24$
\end{tabular}

Table A5: Compounds included in the stress compound mixture used for positive identification in PINOT NOIR samples.

\begin{tabular}{lll}
\hline Methyl salicylate & $119-36-8$ & $\mathrm{C} 8 \mathrm{H} 8 \mathrm{O} 3$ \\
\hline Z-Hexenyl acetate & $3681-71-8$ & $\mathrm{C} 8 \mathrm{H} 14 \mathrm{O} 2$ \\
\hline (E)- $\beta$-Ocimene & $3779-61-1$ & $\mathrm{C} 10 \mathrm{H} 16$ \\
\hline (Z)- $\beta$-Ocimene & $3338-55-4$ & $\mathrm{C} 10 \mathrm{H} 16$ \\
\hline Farnesene (isomer mixture) & & $\mathrm{C} 15 \mathrm{H} 24$
\end{tabular}




\section{Appendix E: Data Analysis Steps}

1. Standard Groups

Positive identification of similar compounds using only mass spectral data is very difficult.

While there is a general order we expect compounds to elute, some will elute so closely that changes in the column can swap the order (See $\beta$-pinene and $\beta$-myrcene in Appendices $F$ and $G$ ). Instead of analyzing all the authentic standards at once, they are run in four groups, with each group not containing any two compounds that would be difficult to distinguish. By processing the groups first, the order compounds elute can be established before moving onto more complex samples.

\section{Analysis of Standards}

Various concentrations $(.5-25 \mathrm{ng} / \mu \mathrm{l})$ of the mixture of authentic standards are spiked onto cartridges and analyzed on the GCXGC/TOFMS. These standards can be used for quantification and positive identification of samples. They also provide a road map to where to look in the chromatogram for compound types (FigureA1).

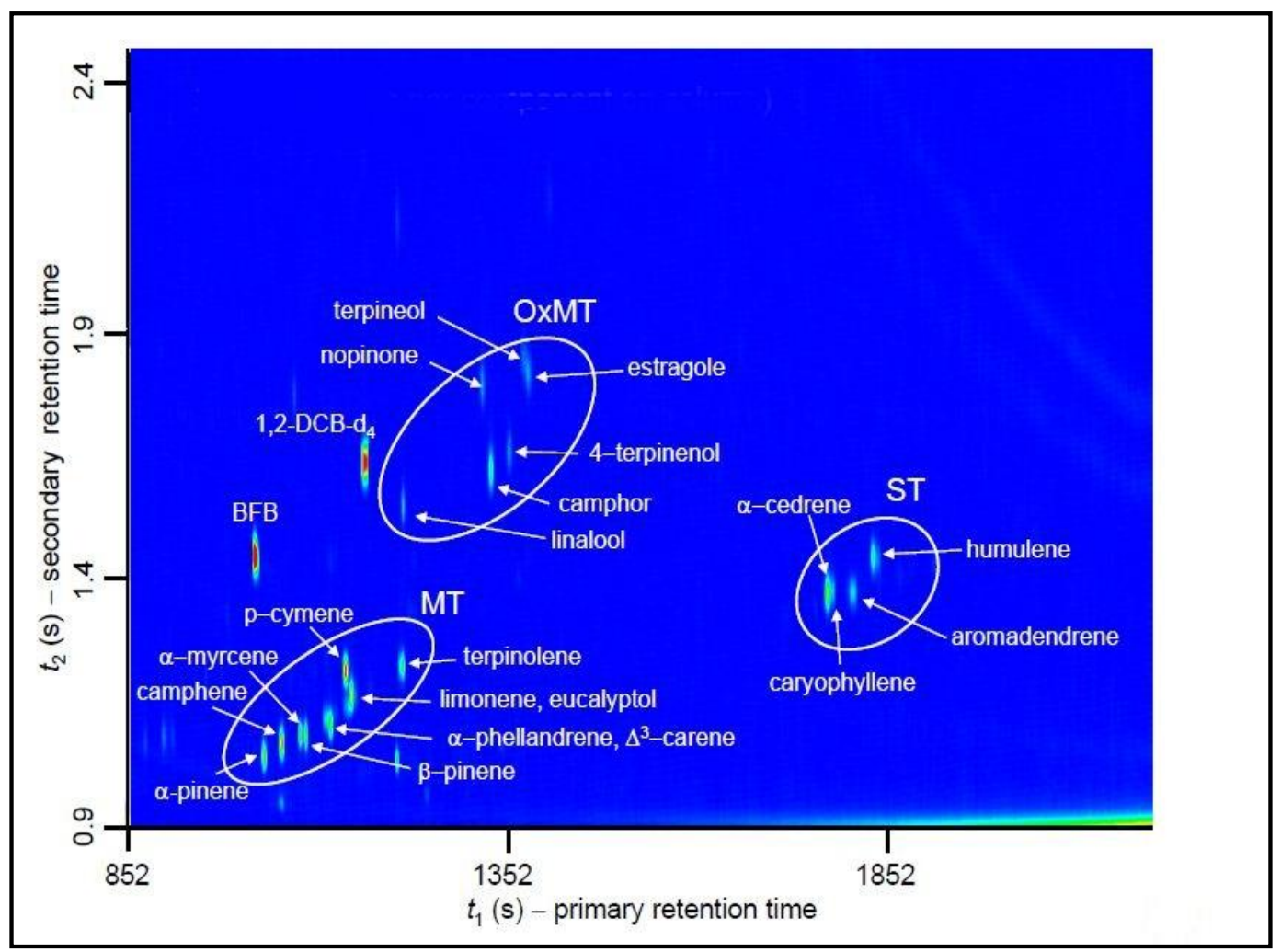

Figure A1: 3D chromatogram of standards taken from Pankow et al., 2012. Regions of the chromatogram have been been circled and labeled to show how similar compounds elute in predictable regions. 
Each compound in the mixture of standards must be identified. This is done by moving through the chromatogram and looking at each compound individually. Using the order established in Step 1, identification is typically straight forward. The LECO software returns a "top ten" hit list based on mass spectral match. For many compounds, the LECO hit list includes the actual compound name and it can be selected. For some compounds, such as $\beta$-pinene, the LECO software is never able to appropriately identify the compound and it must be done manually.

\section{Calculation of Response Factors}

The various concentrations of the mixture of authentic standards are used to determine the instrument response factor (RF). Using Equation 3 (Methods section), the relative RF is calculated for each compound, and for each concentration. The RF for each concentration is then averaged to obtain the overall instrument RF for each compound in the authentic standard mixture.

\section{4. $\quad$ Filtering of Non-Target Analytes}

Due to the sensitivity of the $G C \times G C$ there may be hundreds, if not more, compounds which elute in a solvent smear low on the chromatogram (below the alkanes) and late in the sample (after the oxygenated sesquiterpenes). These can come from column bleeding or the solvent (e.g. methanol) used to make the standard mixture. Using the standards as a guide, the LECO software allows you to draw filtered regions on the chromatogram (Figure A2).

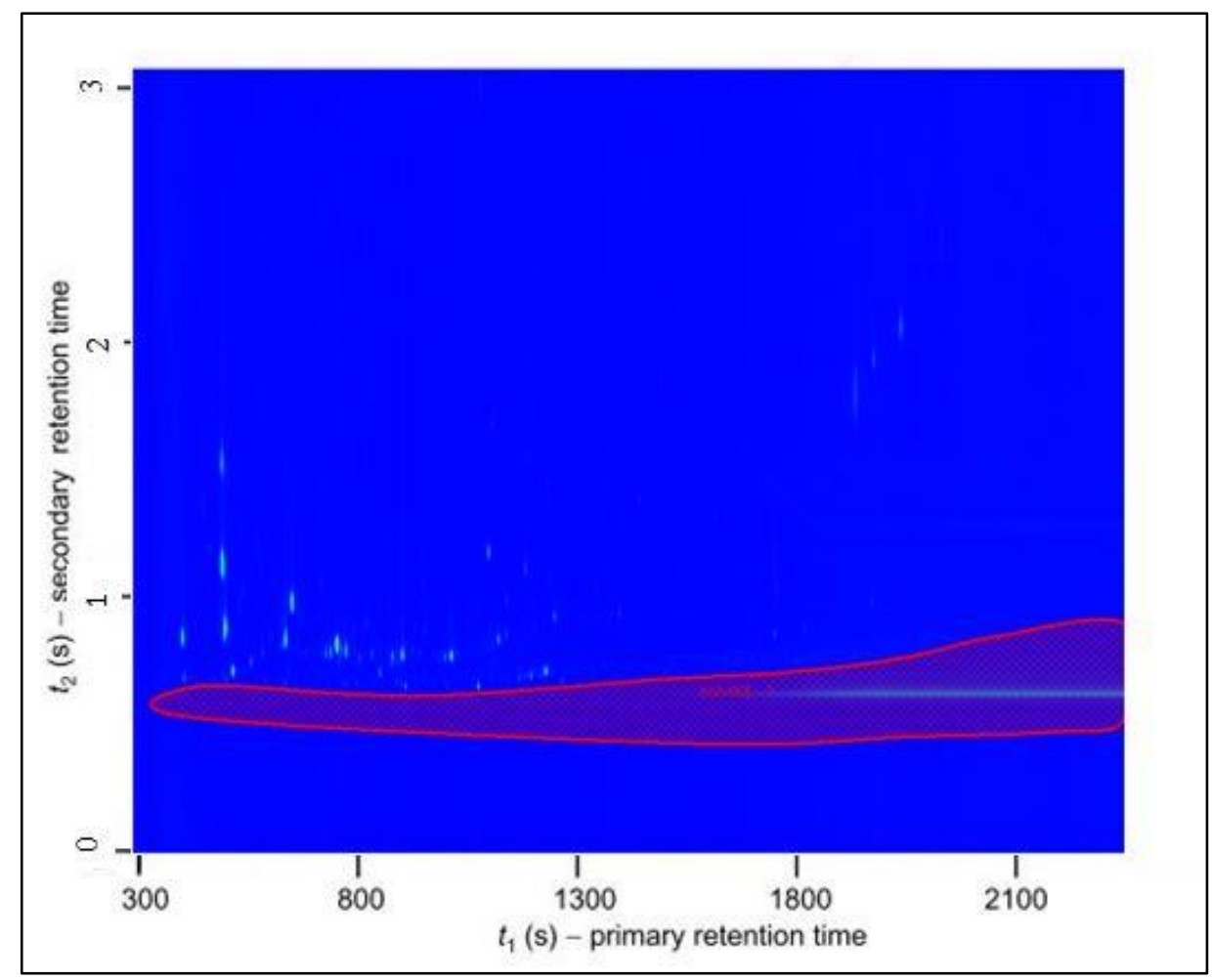

Figure A2: Solvent region used to filter undesired compounds in the LECO software. 


\section{Processing samples}

A peak selection criteria (PSC) is applied to each of the samples. The PSC requires a signal to noise ratio $>200$. Peaks are shown on the chromatogram, but also in a table which can be sorted based on a wide range of criteria. After this is applied, and the solvent region is filtered out, the peak table for a typical ambient air sample contains 1000-2000 entries.

\section{Targeted Analysis}

Using retention times of standards, samples can be analyzed for these compounds. Once found, a series of questions must be applied

a) Do retention times for both dimensions match those of a standard?

b) Does the library mass spectrum match this compound?

c) Is the standard included in the LECO hit list?

a. If no, does this compound require manual identification?

d) Was the peak falsely divided into two peaks which need to be combined?

e) Are there any "false peaks"? - typically occurring between two real peaks, the LECO software sometimes falsely applies ions to a third, non-real peak which should be deleted.

\section{Non-Targeted Analysis}

Once the targeted analysis is complete, then the other peaks in the sample must be examined.

a) Is the compound possibly a terpene or its oxidation product?

b) Is the compound another biogenic emission, such as a green leaf volatile?

c) Does the LECO hit list include a likely identification? (Often, the "top ten" hit list will include compounds that it definitely is not. The is particularly true of terpenes, which are repeatedly identified as $\alpha$-pinene or $\alpha$-phellandrene)

d) Can the identification be confirmed using retention index information?

e) Was the peak falsely divided into two peaks which need to be combined?

f) Are there any "false peaks"? - typically occurring between two real peaks, the LECO software sometimes falsely applies ions to a third, non-real peak which should be deleted.

\section{Export to Excel}

Each sample can be exported to an Excel file. Once in Excel, compounds that are not of interest can be deleted. For this work, compounds that were not of interest were all non-biogenic VOCs, such as:

- Silica containing compounds (these appear to be a remnant of the columns)

- Anthropogenic compounds

- Trace Gases- $\mathrm{NO}_{2}$, etc.

- Sulfur and nitrogen containing compounds 
9. Identification of Alkanes in the Samples

Straight chained alkanes are needed for calculation of retention indices. While alkanes are not always correctly identified by the LECO software, they often fall in a predictable pattern in the chromatogram. This, together with the mass spectrum and LECO hit list, allows for the identification of naturally present alkanes (Figure A3).

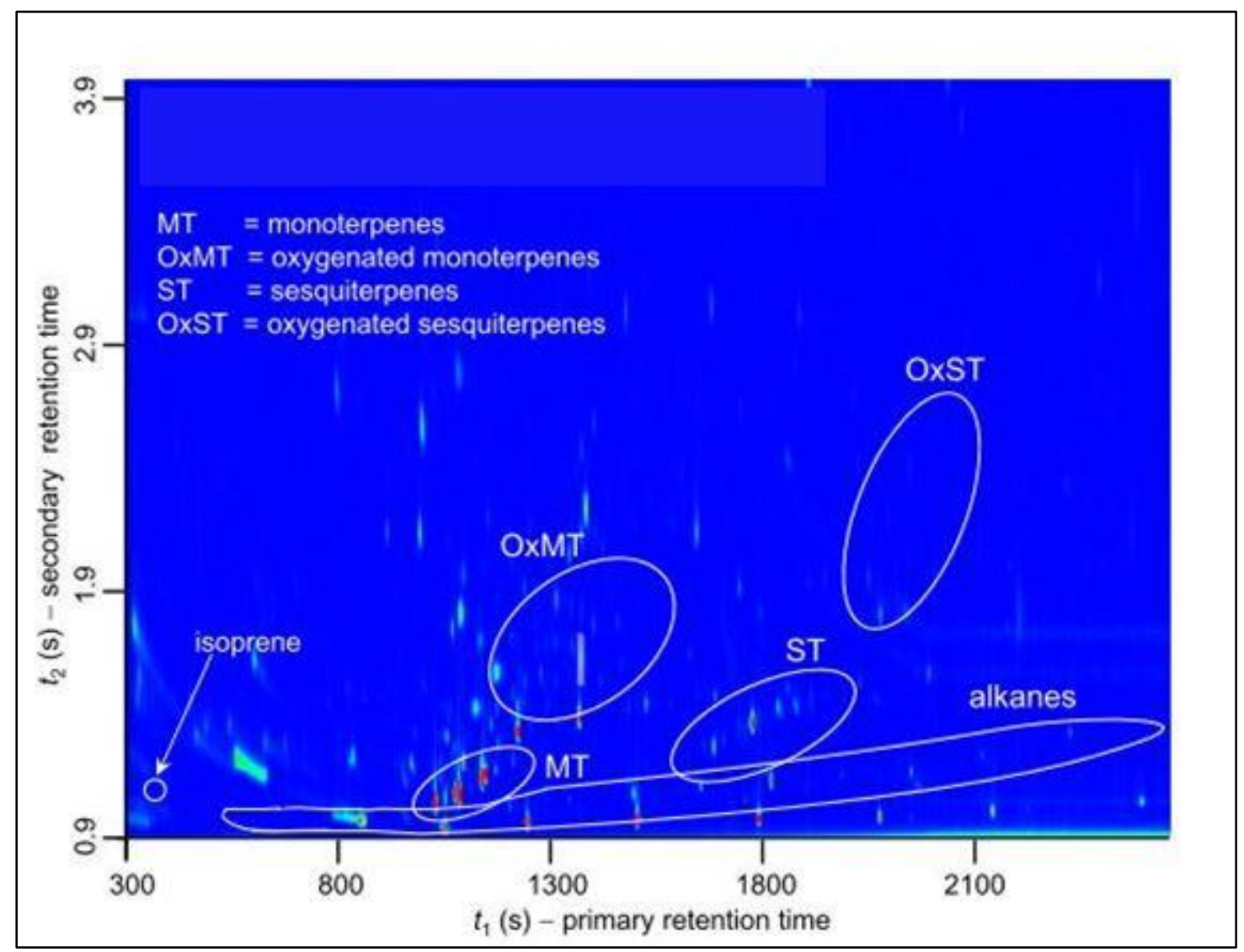

Figure A3: Chromatogram from Pankow et al., 2012 showing the pattern of eluting alkanes in relation to other targeted compounds.

\section{Calculation of Retention Indices}

Using the naturally present alkanes in samples, retention indices are calculated for all of the analytes of interest (Equations 1 and 2, Methods)

\section{Additional Attempts to identify Anlytes in a Sample}

By comparing to published retention indices, unidentified/tentatively identified analytes may be more confidently identified. If a possible match has been found, the LECO software is again consulted for comparison to mass spectral data. 
12. Quantification of Analytes in a Sample

Using the calculated response factor (Equation 3, Methods) the area of an analyte can be compared to a known mass of the internal standard to determine the mass of an analyte in the sample. Sample volume is then used to calculate concentration $\left(\mu \mathrm{g} / \mathrm{m}^{3}\right)$ and then temperature and molecular weight can be used to determine mixing ratio (PPBv). 


\section{Appendix F: Compound List-BEACHON-RoMBAS}

Table A6: Compounds found in BEACHON-RoMBAS samples. Bold: Compounds identified using authentic standards and mass spectral data organized using first dimensional retention index (I) and second dimension retention ration (R). Regular: Identified using mass spectral data and published retention indices. Italics: Identified using only mass spectral data.

\begin{tabular}{|c|c|c|c|}
\hline Identification & Formula & $\mathbf{I}$ & $\mathbf{R}$ \\
\hline Isoprene & $\mathrm{C} 5 \mathrm{H} 8$ & 530 & 1.053 \\
\hline Methacrolein & $\mathrm{C} 4 \mathrm{H} 6 \mathrm{O}$ & 572 & 1.253 \\
\hline Methyl vinyl ketone & $\mathrm{C} 4 \mathrm{H} 6 \mathrm{O}$ & 593 & 1.348 \\
\hline 2-methyl-3-Buten-2-ol (MBO) & $\mathrm{C} 5 \mathrm{H} 100$ & 612 & 1.445 \\
\hline $\mathrm{C} 10 \mathrm{H} 16$ isomer & $\mathrm{C} 10 \mathrm{H} 16$ & 900 & 1.015 \\
\hline Bornylene & $\mathrm{C} 10 \mathrm{H} 16$ & 922 & 1.025 \\
\hline $\mathrm{C} 10 \mathrm{H} 18$ isomer & $\mathrm{C} 10 \mathrm{H} 18$ & 947 & 1.025 \\
\hline Tricyclene & $\mathrm{C} 10 \mathrm{H} 16$ & 947 & 1.040 \\
\hline á-Pinene & $\mathrm{C} 10 \mathrm{H} 16$ & 956 & 1.037 \\
\hline $\mathrm{C} 10 \mathrm{H} 16$ isomer & $\mathrm{C} 10 \mathrm{H} 16$ & 962 & 1.065 \\
\hline$\alpha$-Fenchene & $\mathrm{C} 10 \mathrm{H} 16$ & 975 & 1.075 \\
\hline Camphene & $\mathrm{C} 10 \mathrm{H} 16$ & 978 & 1.059 \\
\hline 2,4-Thujadiene & $\mathrm{C} 10 \mathrm{H} 14$ & 981 & 1.104 \\
\hline$\beta$-Myrcene & $\mathrm{C} 10 \mathrm{H} 16$ & 994 & 1.084 \\
\hline Sabinene & $\mathrm{C} 10 \mathrm{H} 16$ & 994 & 1.099 \\
\hline m-Cymene & $\mathrm{C} 10 \mathrm{H} 14$ & 1000 & 1.134 \\
\hline 1,3,5-Cycloheptatriene, 3,7,7-trimethyl- & $\mathrm{C} 10 \mathrm{H} 14$ & 1000 & 1.140 \\
\hline$\beta$-Pinene & $\mathrm{C} 10 \mathrm{H} 16$ & 1005 & 1.080 \\
\hline $\mathrm{C} 10 \mathrm{H} 18$ isomer & $\mathrm{C} 10 \mathrm{H} 18$ & 1021 & 1.023 \\
\hline$\alpha$-Phellandrene & $\mathrm{C} 10 \mathrm{H} 16$ & 1024 & 1.117 \\
\hline$\Delta$-3-Carene & $\mathrm{C} 10 \mathrm{H} 16$ & 1032 & 1.091 \\
\hline o-Isopropenyltoluene & $\mathrm{C} 10 \mathrm{H} 12$ & 1032 & 1.231 \\
\hline (Z)- $\beta$-Ocimene & $\mathrm{C} 10 \mathrm{H} 16$ & 1037 & 1.126 \\
\hline Limonene & $\mathrm{C} 10 \mathrm{H} 16$ & 1047 & 1.129 \\
\hline p-Cymene & $\mathrm{C} 10 \mathrm{H} 14$ & 1047 & 1.195 \\
\hline $\mathrm{C} 10 \mathrm{H} 16$ isomer & $\mathrm{C} 10 \mathrm{H} 16$ & 1055 & 1.141 \\
\hline$\beta$-Phellandrene & $\mathrm{C} 10 \mathrm{H} 16$ & 1055 & 1.148 \\
\hline Eucalyptol & $\mathrm{C} 10 \mathrm{H} 18 \mathrm{O}$ & 1055 & 1.155 \\
\hline Benzene, 1-methyl-3-propyl- & $\mathrm{C} 10 \mathrm{H} 14$ & 1071 & 1.236 \\
\hline Y-Terpinene (Moslene) & $\mathrm{C} 10 \mathrm{H} 16$ & 1074 & 1.155 \\
\hline Benzene, 1-methyl-4-propyl- & $\mathrm{C} 10 \mathrm{H} 14$ & 1074 & 1.220 \\
\hline Thujene isomer & $\mathrm{C} 10 \mathrm{H} 14$ & 1079 & 1.233 \\
\hline
\end{tabular}




\begin{tabular}{|c|c|c|c|}
\hline $\mathrm{C} 10 \mathrm{H} 160$ isomer & $\mathrm{C} 10 \mathrm{H} 160$ & 1079 & 1.247 \\
\hline Benzene, 2-ethyl-1,4-dimethyl- & $\mathrm{C} 10 \mathrm{H} 14$ & 1082 & 1.238 \\
\hline Myrcenol & $\mathrm{C} 10 \mathrm{H} 160$ & 1100 & 1.216 \\
\hline Terpinolene & $\mathrm{C} 10 \mathrm{H} 16$ & 1107 & 1.185 \\
\hline p-Cymenene & $\mathrm{C} 10 \mathrm{H} 12$ & 1107 & 1.384 \\
\hline Linalool & $\mathrm{C} 10 \mathrm{H} 180$ & 1107 & 1.499 \\
\hline trans-3-Caren-2-ol & $\mathrm{C} 10 \mathrm{H} 160$ & 1109 & 1.291 \\
\hline o-Cymenene & $\mathrm{C} 10 \mathrm{H} 12$ & 1116 & 1.395 \\
\hline Benzene, (2-methyl-2-propenyl)- & $\mathrm{C} 10 \mathrm{H} 12$ & 1118 & 1.394 \\
\hline trans-2-Caren-4-ol & $\mathrm{C} 10 \mathrm{H} 160$ & 1170 & 1.351 \\
\hline Camphor & $\mathrm{C} 10 \mathrm{H} 160$ & 1195 & 1.467 \\
\hline Borneol & $\mathrm{C} 10 \mathrm{H} 180$ & 1204 & 1.748 \\
\hline Pinocamphone & $\mathrm{C} 10 \mathrm{H} 140$ & 1209 & 1.524 \\
\hline cis-7-Decen-1-al & $\mathrm{C} 10 \mathrm{H} 180$ & 1215 & 1.370 \\
\hline Estragole (methyl chavicol) & $\mathrm{C} 10 \mathrm{H} 12 \mathrm{O} 2$ & 1226 & 1.608 \\
\hline Methyl salicate & $\mathrm{C} 8 \mathrm{H} 8 \mathrm{O} 3$ & 1239 & 1.962 \\
\hline Myrtenal & $\mathrm{C} 10 \mathrm{H} 140$ & 1241 & 1.569 \\
\hline Methyl thymyl ether & $\mathrm{C} 11 \mathrm{H} 160$ & 1250 & 1.360 \\
\hline $\mathrm{C} 10 \mathrm{H} 12 \mathrm{O} 2 \mathrm{Isomer}$ & $\mathrm{C} 10 \mathrm{H} 12 \mathrm{O} 2$ & 1278 & 1.791 \\
\hline 2-Decenal, (Z)- & $\mathrm{C} 10 \mathrm{H} 180$ & 1283 & 1.400 \\
\hline (Z)-Rose oxide & $\mathrm{C} 10 \mathrm{H} 180$ & 1402 & 0.986 \\
\hline Phenol, m-tert-butyl- & $\mathrm{C} 10 \mathrm{H} 140$ & 1402 & 4.011 \\
\hline Phenol, p-tert-butyl- & $\mathrm{C} 10 \mathrm{H} 140$ & 1404 & 3.971 \\
\hline 1,6,6-Trimethyl-8-oxabicyclo[3.2.1]octan-2-one & $\mathrm{C} 10 \mathrm{H} 16 \mathrm{O} 2$ & 1409 & 1.512 \\
\hline$(1 R, 2 R, 3 S, 5 R)-(-)-2,3$-Pinanediol & $\mathrm{C} 10 \mathrm{H} 18 \mathrm{O} 2$ & 1411 & 1.971 \\
\hline Limonene dioxide & $\mathrm{C} 10 \mathrm{H} 16 \mathrm{O} 2$ & 1413 & 1.977 \\
\hline $\mathrm{C} 10 \mathrm{H} 16$ isomer & $\mathrm{C} 10 \mathrm{H} 16$ & 1420 & 1.268 \\
\hline $\mathrm{C} 10 \mathrm{H} 1602$ isomer & $\mathrm{C} 10 \mathrm{H} 16 \mathrm{O} 2$ & 1422 & 2.030 \\
\hline $\mathrm{C} 10 \mathrm{H} 16$ isomer & $\mathrm{C} 10 \mathrm{H} 16$ & 1446 & 1.279 \\
\hline $\mathrm{C} 14 \mathrm{H} 24 \mathrm{O}$ isomer & $\mathrm{C} 14 \mathrm{H} 24 \mathrm{O}$ & 1489 & 1.373 \\
\hline $\mathrm{C} 10 \mathrm{H} 1402$ isomer & $\mathrm{C} 10 \mathrm{H} 14 \mathrm{O} 2$ & 1516 & 1.766 \\
\hline Longifolene & $\mathrm{C} 15 \mathrm{H} 24$ & 1571 & 1.133 \\
\hline $\mathrm{C} 10 \mathrm{H} 180$ isomer & $\mathrm{C} 10 \mathrm{H} 180$ & 1871 & 1.133 \\
\hline
\end{tabular}




\section{Appendix G: Compound List-PINOT NOIR}

Table A7: Compounds found in PINOT-NOIR samples. Bold: Compounds identified using authentic standards and mass spectral data organized using first dimensional retention index (I) and second dimension retention ration (R). Regular: Identified using mass spectral data and published retention indices. Italics: Identified using only mass spectral data.

\begin{tabular}{|c|c|c|c|}
\hline Compound & Formula & $\mathbf{I}$ & $\mathbf{R}$ \\
\hline Isoprene & $\mathrm{C} 5 \mathrm{H} 8$ & 510 & 0.718 \\
\hline $\mathrm{C} 10 \mathrm{H} 2002$ isomer & $\mathrm{C} 10 \mathrm{H} 20 \mathrm{O} 2$ & 561 & 0.778 \\
\hline Methacrolein & $\mathrm{C} 4 \mathrm{H} 6 \mathrm{O}$ & 564 & 1.697 \\
\hline Methyl vinyl ketone & $\mathrm{C} 4 \mathrm{H} 6 \mathrm{O}$ & 590 & 2.591 \\
\hline 3-Buten-2-ol, 2-methyl- & $\mathrm{C} 5 \mathrm{H} 100$ & 610 & 4.101 \\
\hline $\mathrm{C} 1 \mathrm{OH} 18$ isomer & $\mathrm{C} 10 \mathrm{H} 18$ & 794 & 3.719 \\
\hline $\mathrm{C} 12 \mathrm{H} 1803$ isomer & $\mathrm{C} 12 \mathrm{H} 18 \mathrm{O} 3$ & 809 & 0.876 \\
\hline 4-Nonene, 3-methyl-, (Z)- & $\mathrm{C} 10 \mathrm{H} 20$ & 811 & 0.812 \\
\hline 1,5-Heptadien-4-one, 3,3,6-trimethyl- & $\mathrm{C} 10 \mathrm{H} 16 \mathrm{O}$ & 834 & 0.773 \\
\hline $\mathrm{C} 10 \mathrm{H} 20$ isomer & $\mathrm{C} 10 \mathrm{H} 20$ & 838 & 0.806 \\
\hline 2-Methylbutanoic anhydride & $\mathrm{C} 10 \mathrm{H} 18 \mathrm{O} 3$ & 843 & 0.751 \\
\hline Cyclohexane, 1,1,3,5-tetramethyl-, cis- & $\mathrm{C} 10 \mathrm{H} 20$ & 894 & 0.784 \\
\hline Cyclohexane, 1,1,3,5-tetramethyl-, trans- & $\mathrm{C} 10 \mathrm{H} 20$ & 894 & 0.789 \\
\hline $\mathrm{C} 11 \mathrm{H} 200$ isomer & $\mathrm{C} 11 \mathrm{H} 200$ & 896 & 0.778 \\
\hline $\mathrm{C} 10 \mathrm{H} 1803$ isomer & $\mathrm{C} 10 \mathrm{H} 18 \mathrm{O} 3$ & 896 & 0.778 \\
\hline Cyclohexane, 1,1,4,4-tetramethyl- & $\mathrm{C} 10 \mathrm{H} 20$ & 914 & 0.801 \\
\hline 3,4-Diethyl-3-hexene & $\mathrm{C} 10 \mathrm{H} 20$ & 918 & 0.745 \\
\hline Tricyclene & $\mathrm{C} 10 \mathrm{H} 16$ & 930 & 0.948 \\
\hline$\alpha$-Thujene & $\mathrm{C} 10 \mathrm{H} 16$ & 930 & 0.954 \\
\hline $\mathrm{C} 10 \mathrm{H} 20$ isomer & $\mathrm{C} 10 \mathrm{H} 20$ & 935 & 0.795 \\
\hline $\mathrm{C} 10 \mathrm{H} 20$ isomer & $\mathrm{C} 10 \mathrm{H} 20$ & 939 & 0.806 \\
\hline $\mathrm{C} 10 \mathrm{H} 160$ isomer & $\mathrm{C} 10 \mathrm{H} 160$ & 939 & 0.823 \\
\hline$\alpha$-Pinene & $\mathrm{C} 10 \mathrm{H} 16$ & 941 & 0.942 \\
\hline $\mathrm{C} 10 \mathrm{H} 20$ isomer & $\mathrm{C} 10 \mathrm{H} 20$ & 945 & 0.795 \\
\hline $\mathrm{C} 10 \mathrm{H} 20$ isomer & $\mathrm{C} 10 \mathrm{H} 20$ & 946 & 0.812 \\
\hline $\mathrm{C} 10 \mathrm{H} 20$ isomer & $\mathrm{C} 10 \mathrm{H} 20$ & 951 & 0.801 \\
\hline $\mathrm{C} 11 \mathrm{H} 200$ isomer & $\mathrm{C} 11 \mathrm{H} 200$ & 955 & 0.835 \\
\hline Camphene & $\mathrm{C} 10 \mathrm{H} 16$ & 957 & 1.042 \\
\hline $\mathrm{C} 10 \mathrm{H} 20$ isomer & $\mathrm{C} 10 \mathrm{H} 20$ & 964 & 0.812 \\
\hline Cyclopropane, 1-methyl-2-(3-methylpentyl)- & $\mathrm{C} 10 \mathrm{H} 20$ & 964 & 0.818 \\
\hline 2-Octene, 3,7-dimethyl-, (Z)- & $\mathrm{C} 10 \mathrm{H} 20$ & 966 & 0.818 \\
\hline $\mathrm{C} 10 \mathrm{H} 20$ isomer & $\mathrm{C} 10 \mathrm{H} 20$ & 966 & 0.846 \\
\hline
\end{tabular}




\begin{tabular}{|c|c|c|c|}
\hline Cyclopropane, 1,2-dimethyl-3-pentyl-, (1à,2à,3à)- & $\mathrm{C} 10 \mathrm{H} 20$ & 975 & 0.812 \\
\hline 5-Decene, $(E)-$ & $\mathrm{C} 10 \mathrm{H} 20$ & 975 & 0.818 \\
\hline Sabinene & $\mathrm{C} 10 \mathrm{H} 16$ & 979 & 1.127 \\
\hline Heptane, 2,2,3,5-tetramethyl- & $\mathrm{C} 11 \mathrm{H} 24$ & 981 & 0.724 \\
\hline $\mathrm{C} 10 \mathrm{H} 20$ isomer & $\mathrm{C} 10 \mathrm{H} 20$ & 982 & 0.823 \\
\hline 1,4-Hexadiene, 3-ethyl-4,5-dimethyl- & $\mathrm{C} 10 \mathrm{H} 18$ & 983 & 0.923 \\
\hline$\beta$-Pinene & $\mathrm{C} 10 \mathrm{H} 16$ & 985 & 1.094 \\
\hline 2-Nonene, 3-methyl-, (E)- & $\mathrm{C} 10 \mathrm{H} 20$ & 986 & 0.835 \\
\hline $\mathrm{C} 10 \mathrm{H} 20$ isomer & $\mathrm{C} 10 \mathrm{H} 20$ & 992 & 0.823 \\
\hline$\beta$-Myrcene & $\mathrm{C} 10 \mathrm{H} 16$ & 992 & 1.161 \\
\hline $\mathrm{C} 10 \mathrm{H} 20$ isomer & $\mathrm{C} 10 \mathrm{H} 20$ & 995 & 0.835 \\
\hline 1,1'-Bicycloheptyl & $\mathrm{C} 14 \mathrm{H} 26$ & 998 & 0.876 \\
\hline Benzene, tert-butyl- & $\mathrm{C} 10 \mathrm{H} 14$ & 1003 & 1.565 \\
\hline 3,4-Diethyl-2-hexene & $\mathrm{C} 10 \mathrm{H} 20$ & 1009 & 0.778 \\
\hline$\alpha$-Phellandrene & $\mathrm{C} 10 \mathrm{H} 16$ & 1012 & 1.181 \\
\hline 3-Carene & $\mathrm{C} 10 \mathrm{H} 16$ & 1017 & 1.107 \\
\hline Benzene, (1-methylpropyl)- & $\mathrm{C} 10 \mathrm{H} 14$ & 1020 & 1.542 \\
\hline Oxalic acid, bis(isobutyl) ester & $\mathrm{C} 10 \mathrm{H} 18 \mathrm{O} 4$ & 1023 & 0.734 \\
\hline $\begin{array}{l}\text { 3-Cyclopentylpropionic acid, 2- } \\
\text { tetrahydrofurylmethyl ester }\end{array}$ & $\mathrm{C} 13 \mathrm{H} 22 \mathrm{O} 3$ & 1023 & 0.745 \\
\hline $\mathrm{C} 10 \mathrm{H} 20$ isomer & $\mathrm{C} 10 \mathrm{H} 20$ & 1025 & 0.801 \\
\hline$\alpha$-Terpinene & $\mathrm{C} 10 \mathrm{H} 16$ & 1025 & 1.188 \\
\hline $\mathrm{C} 10 \mathrm{H} 14$ isomer & $\mathrm{C} 10 \mathrm{H} 14$ & 1031 & 1.542 \\
\hline Cyclohexane, butyl- & $\mathrm{C} 10 \mathrm{H} 20$ & 1037 & 0.882 \\
\hline Limonene & $\mathrm{C} 10 \mathrm{H} 16$ & 1037 & 1.215 \\
\hline p-Cymene & $\mathrm{C} 10 \mathrm{H} 14$ & 1037 & 1.550 \\
\hline (Z)- $\beta$-Ocimene & $\mathrm{C} 10 \mathrm{H} 16$ & 1039 & 1.250 \\
\hline Cyclopentane, (3-methylbutyl)- & $\mathrm{C} 10 \mathrm{H} 20$ & 1041 & 0.846 \\
\hline C11H20O isomer & $\mathrm{C} 11 \mathrm{H} 200$ & 1041 & 0.852 \\
\hline Cyclodecane & $\mathrm{C} 10 \mathrm{H} 20$ & 1041 & 0.858 \\
\hline$\beta$-Phellandrene & $\mathrm{C} 10 \mathrm{H} 16$ & 1041 & 1.271 \\
\hline $\mathrm{C} 10 \mathrm{H} 180$ isomer & $\mathrm{C} 10 \mathrm{H} 180$ & 1048 & 0.734 \\
\hline (E)- $\beta$-Ocimene & $\mathrm{C} 10 \mathrm{H} 16$ & 1052 & 1.271 \\
\hline $\begin{array}{l}\text { 5-Methyl-2-(2-methyl-2- } \\
\text { tetrahydrofuryl)tetrahydrofuran }\end{array}$ & $\mathrm{C} 10 \mathrm{H} 18 \mathrm{O} 2$ & 1063 & 0.718 \\
\hline Benzene, 1-methyl-3-propyl- & $\mathrm{C} 10 \mathrm{H} 14$ & 1063 & 1.580 \\
\hline Y-Terpinene (Moslene) & $\mathrm{C} 10 \mathrm{H} 16$ & 1064 & 1.271 \\
\hline $\mathrm{C} 10 \mathrm{H} 16$ isomer & $\mathrm{C} 10 \mathrm{H} 16$ & 1066 & 1.264 \\
\hline $\mathrm{C} 10 \mathrm{H} 14$ isomer & $\mathrm{C} 10 \mathrm{H} 14$ & 1067 & 1.611 \\
\hline $\mathrm{C} 10 \mathrm{H} 14$ isomer & $\mathrm{C} 10 \mathrm{H} 14$ & 1074 & 1.626 \\
\hline
\end{tabular}




\begin{tabular}{|c|c|c|c|}
\hline 7-Octen-2-ol, 2,6-dimethyl- & $\mathrm{C} 10 \mathrm{H} 20 \mathrm{O}$ & 1075 & 2.375 \\
\hline Cyclohexane, 2,4-diisopropyl-1,1-dimethyl- & $\mathrm{C} 14 \mathrm{H} 28$ & 1077 & 0.806 \\
\hline 2,2'-Bi-2H-pyran, octahydro- & $\mathrm{C} 10 \mathrm{H} 18 \mathrm{O} 2$ & 1078 & 0.734 \\
\hline Cyclooctane, 1,4-dimethyl-, cis- & $\mathrm{C} 10 \mathrm{H} 20$ & 1083 & 0.801 \\
\hline $\mathrm{C} 10 \mathrm{H} 20$ isomer & $\mathrm{C} 10 \mathrm{H} 20$ & 1088 & 0.801 \\
\hline Terpinolene & $\mathrm{C} 10 \mathrm{H} 16$ & 1092 & 1.321 \\
\hline $\mathrm{C} 10 \mathrm{H} 1602$ isomer & $\mathrm{C} 10 \mathrm{H} 16 \mathrm{O} 2$ & 1094 & 0.812 \\
\hline $\mathrm{C} 1 \mathrm{OH} 14$ isomer & $\mathrm{C} 10 \mathrm{H} 14$ & 1094 & 1.673 \\
\hline $\mathrm{C} 10 \mathrm{H} 20$ isomer & $\mathrm{C} 10 \mathrm{H} 20$ & 1097 & 0.773 \\
\hline $\mathrm{C} 1 \mathrm{OH} 14$ isomer & $\mathrm{C} 10 \mathrm{H} 14$ & 1097 & 1.704 \\
\hline $\mathrm{C} 11 \mathrm{H} 24$ isomer & $\mathrm{C} 11 \mathrm{H} 24$ & 1100 & 0.767 \\
\hline $\mathrm{C} 10 \mathrm{H} 14$ isomer & $\mathrm{C} 10 \mathrm{H} 14$ & 1102 & 1.736 \\
\hline Linalool & $\mathrm{C} 10 \mathrm{H} 180$ & 1102 & 2.896 \\
\hline Benzene, 1-methyl-4-(1-methylethenyl)- & $\mathrm{C} 10 \mathrm{H} 12$ & 1105 & 2.167 \\
\hline Cyclohexane, 2-ethenyl-1,1-dimethyl-3-methylene- & $\mathrm{C} 11 \mathrm{H} 18$ & 1119 & 1.208 \\
\hline Benzene, 2-ethyl-1,3-dimethyl- & $\mathrm{C} 10 \mathrm{H} 14$ & 1124 & 1.880 \\
\hline $\mathrm{C} 10 \mathrm{H} 200$ isomer & $\mathrm{C} 11 \mathrm{H} 200$ & 1131 & 0.858 \\
\hline $\begin{array}{l}\text { 1,3-Cyclopentadiene, 1,2,3,4-tetramethyl-5- } \\
\text { methylene- }\end{array}$ & $\mathrm{C} 10 \mathrm{H} 14$ & 1144 & 1.840 \\
\hline Benzene, 1,2,3,4-tetramethyl- & $\mathrm{C} 10 \mathrm{H} 14$ & 1148 & 1.904 \\
\hline Acetic acid, 2-ethylhexyl ester & $\mathrm{C} 10 \mathrm{H} 20 \mathrm{O} 2$ & 1153 & 1.349 \\
\hline Benzene, 1-methyl-4-(1-methylpropyl)- & $\mathrm{C} 11 \mathrm{H} 16$ & 1158 & 1.527 \\
\hline 1H-Indene, 2,3-dihydro-4-methyl- & $\mathrm{C} 10 \mathrm{H} 12$ & 1160 & 2.167 \\
\hline $\mathrm{C} 10 \mathrm{H} 200$ isomer & $\mathrm{C} 10 \mathrm{H} 20 \mathrm{O}$ & 1177 & 1.626 \\
\hline Benzene, 1,2,4,5-tetramethyl- & $\mathrm{C} 10 \mathrm{H} 14$ & 1180 & 2.059 \\
\hline $\mathrm{C} 10 \mathrm{H} 12$ isomer & $\mathrm{C} 10 \mathrm{H} 12$ & 1182 & 2.433 \\
\hline Cyclohexanone, 4-(1,1-dimethylpropyl)- & $\mathrm{C} 11 \mathrm{H} 20 \mathrm{O}$ & 1189 & 1.760 \\
\hline $\mathrm{C} 10 \mathrm{H} 20$ isomer & $\mathrm{C} 10 \mathrm{H} 20$ & 1192 & 0.864 \\
\hline C11H24 isomer & $\mathrm{C} 11 \mathrm{H} 24$ & 1199 & 0.784 \\
\hline 2-Decanone & $\mathrm{C} 10 \mathrm{H} 20 \mathrm{O}$ & 1199 & 1.712 \\
\hline Cyclohexanol, 3,3,5-trimethyl-, acetate, cis- & $\mathrm{C} 11 \mathrm{H} 2002$ & 1201 & 1.542 \\
\hline $\mathrm{C} 10 \mathrm{H} 200$ isomer & $\mathrm{C} 10 \mathrm{H} 20 \mathrm{O}$ & 1212 & 1.681 \\
\hline 1,7-Nonadien-4-ol, 4,8-dimethyl- & $\mathrm{C} 11 \mathrm{H} 20 \mathrm{O}$ & 1259 & 1.650 \\
\hline 2-Decenal, (Z)- & $\mathrm{C} 10 \mathrm{H} 180$ & 1275 & 2.241 \\
\hline 5-Undecanone & $\mathrm{C} 11 \mathrm{H} 22 \mathrm{O}$ & 1277 & 1.467 \\
\hline $\mathrm{C} 10 \mathrm{H} 160$ isomer & $\mathrm{C} 10 \mathrm{H} 160$ & 1303 & 2.928 \\
\hline 1,3-Benzodioxole, 5-(1-propenyl)-, (Z)- & $\mathrm{C} 10 \mathrm{H} 10 \mathrm{O} 2$ & 1307 & 4.173 \\
\hline Undecanal & $\mathrm{C} 11 \mathrm{H} 22 \mathrm{O}$ & 1314 & 1.642 \\
\hline $\mathrm{C} 10 \mathrm{H} 20$ isomer & $\mathrm{C} 10 \mathrm{H} 20$ & 1336 & 0.806 \\
\hline $\mathrm{C} 11 \mathrm{H} 24$ isomer & $\mathrm{C} 11 \mathrm{H} 24$ & 1340 & 0.756 \\
\hline
\end{tabular}




\begin{tabular}{|c|c|c|c|}
\hline Ethanone, 1-[4-(1-methylethyl)phenyl]- & $\mathrm{C} 11 \mathrm{H} 14 \mathrm{O}$ & 1340 & 3.615 \\
\hline $\mathrm{C} 10 \mathrm{H} 20$ isomer & $\mathrm{C} 10 \mathrm{H} 20$ & 1352 & 0.823 \\
\hline Cyclohexanone, 3-butyl- & $\mathrm{C} 10 \mathrm{H} 180$ & 1359 & 0.806 \\
\hline 2,4,4-Trimethyl-3-(3-methylbutyl)cyclohex-2-enone & $\mathrm{C} 14 \mathrm{H} 24 \mathrm{O}$ & 1373 & 2.225 \\
\hline 2-Undecenal & $\mathrm{C} 11 \mathrm{H} 20 \mathrm{O}$ & 1379 & 2.167 \\
\hline $\begin{array}{l}\text { 2-Pentanone, 3-[(acetyloxy)methyl]-3,4-dimethyl-, } \\
\text { (.+-.)- }\end{array}$ & $\mathrm{C} 10 \mathrm{H} 18 \mathrm{O} 3$ & 1381 & 0.784 \\
\hline Cyclopentane, (2-methylbutyl)- & $\mathrm{C} 10 \mathrm{H} 20$ & 1402 & 0.882 \\
\hline 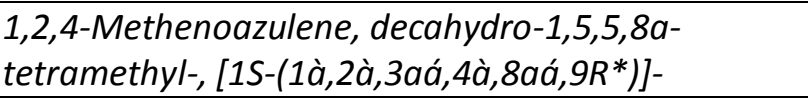 & $\mathrm{C} 15 \mathrm{H} 24$ & 1405 & 1.208 \\
\hline Cyclopentanone, 2-cyclopentylidene- & $\mathrm{C} 10 \mathrm{H} 140$ & 1411 & 3.753 \\
\hline $\mathrm{C} 10 \mathrm{H} 20$ isomer & $\mathrm{C} 10 \mathrm{H} 20$ & 1415 & 0.923 \\
\hline $\mathrm{C} 11 \mathrm{H} 200$ isomer & $\mathrm{C} 11 \mathrm{H} 200$ & 1428 & 1.042 \\
\hline Longifolene & $\mathrm{C} 15 \mathrm{H} 24$ & 1440 & 1.321 \\
\hline$\alpha$-Cedrene & $\mathrm{C} 15 \mathrm{H} 24$ & 1447 & 1.278 \\
\hline Geranyl acetone & $\mathrm{C} 13 \mathrm{H} 22 \mathrm{O}$ & 1461 & 2.142 \\
\hline Thujopsene & $\mathrm{C} 15 \mathrm{H} 24$ & 1464 & 1.386 \\
\hline $\begin{array}{l}\text { 4-(1-Hydroperoxy-2,2-dimethyl-6-methylene- } \\
\text { cyclohexyl)-pent-3-en-2-one }\end{array}$ & $\mathrm{C} 14 \mathrm{H} 22 \mathrm{O} 3$ & 1480 & 3.801 \\
\hline Menthol, 1'-(butyn-3-one-1-yl)-, $(1 S, 2 S, 5 R)-$ & $\mathrm{C} 14 \mathrm{H} 22 \mathrm{O} 2$ & 1483 & 3.774 \\
\hline Cyclohexane, 2-ethyl-1,3-dimethyl- & $\mathrm{C} 10 \mathrm{H} 20$ & 1491 & 0.806 \\
\hline Cyclohexane, (1-methylpropyl)- & $\mathrm{C} 10 \mathrm{H} 20$ & 1508 & 0.899 \\
\hline 6,11-Dimethyl-2,6,10-dodecatrien-1-ol & $\mathrm{C} 14 \mathrm{H} 24 \mathrm{O}$ & 1510 & 1.250 \\
\hline 5-tert-Butylpyrogallol & $\mathrm{C} 10 \mathrm{H} 14 \mathrm{O} 3$ & 1512 & 3.306 \\
\hline Cyclohexane, 1-isopropyl-1-methyl- & $\mathrm{C} 10 \mathrm{H} 20$ & 1516 & 0.923 \\
\hline Oxalic acid, cyclohexylmethyl isohexyl ester & $\mathrm{C} 15 \mathrm{H} 26 \mathrm{O} 4$ & 1521 & 0.948 \\
\hline Butylated Hydroxytoluene & $\mathrm{C} 15 \mathrm{H} 240$ & 1525 & 2.043 \\
\hline $\begin{array}{l}\text { Benzene, 1-methyl-4-(1,2,2-trimethylcyclopentyl)-, } \\
\text { (R)- }\end{array}$ & $\mathrm{C} 15 \mathrm{H} 22$ & 1538 & 1.848 \\
\hline Benzene, (1-butylhexyl)- & $\mathrm{C} 16 \mathrm{H} 26$ & 1544 & 1.271 \\
\hline $\begin{array}{l}\text { Naphthalene, 1,2,3,4-tetrahydro-1,6-dimethyl-4-(1- } \\
\text { methylethyl)-, (1S-cis)- }\end{array}$ & $\mathrm{C} 15 \mathrm{H} 22$ & 1549 & 1.760 \\
\hline $\mathrm{C} 10 \mathrm{H} 20$ isomer & $\mathrm{C} 10 \mathrm{H} 20$ & 1551 & 0.806 \\
\hline Benzene, (1-propylheptyl)- & $\mathrm{C} 16 \mathrm{H} 26$ & 1555 & 1.292 \\
\hline $\mathrm{C} 10 \mathrm{H} 20$ isomer & $\mathrm{C} 10 \mathrm{H} 20$ & 1564 & 0.784 \\
\hline 1,4-Hexadiene, 2,3,4,5-tetramethyl- & $\mathrm{C} 10 \mathrm{H} 18$ & 1598 & 1.250 \\
\hline $\mathrm{C} 10 \mathrm{H} 20$ isomer & $\mathrm{C} 10 \mathrm{H} 20$ & 1609 & 0.841 \\
\hline $\begin{array}{l}\text { Propanoic acid, 2-methyl-, 1-(1,1-dimethylethyl)-2- } \\
\text { methyl-1,3-propanediyl ester }\end{array}$ & $\mathrm{C} 16 \mathrm{H} 30 \mathrm{O} 4$ & 1613 & 1.452 \\
\hline Cyclohexane, 1-(cyclohexylmethyl)-2-methyl-, cis- & $\mathrm{C} 14 \mathrm{H} 26$ & 1621 & 0.960 \\
\hline $\mathrm{C} 11 \mathrm{H} 200$ isomer & $\mathrm{C} 11 \mathrm{H} 200$ & 1626 & 1.061 \\
\hline
\end{tabular}




\begin{tabular}{|l|c|c|c|} 
Lauryl acrylate & $\mathrm{C} 15 \mathrm{H} 28 \mathrm{O} 2$ & 1690 & 1.527 \\
\hline 2,6-Diisopropylnaphthalene & $\mathrm{C} 16 \mathrm{H} 20$ & 1701 & 2.475 \\
\hline C10H2O isomer & $\mathrm{C} 10 \mathrm{H} 20$ & 1718 & 0.973 \\
\hline Benzoic acid, 2-ethylhexyl ester & $\mathrm{C} 15 \mathrm{H} 22 \mathrm{O} 2$ & 1722 & 2.383 \\
\hline 2-Ethylhexyl salicylate & $\mathrm{C} 15 \mathrm{H} 22 \mathrm{O} 3$ & 1814 & 2.483 \\
\hline $\begin{array}{l}\text { 1,2-Benzenedicarboxylic acid, bis(2-methylpropyl) } \\
\text { ester }\end{array}$ & $\mathrm{C} 16 \mathrm{H} 22 \mathrm{O} 4$ & 1855 & 3.536 \\
\hline Homosalate & $\mathrm{C} 16 \mathrm{H} 22 \mathrm{O} 3$ & 1874 & 3.024 \\
\hline
\end{tabular}

